\title{
Representação e história da antigaa Estação Ferroviária de Goiânia e da antigaa Rodoferroviária de Brasília documentadas por sketches
}

DOI: $10.20396 /$ labore.v15i00.8666174

Dossiê Documentação do Patrimônio Cultural

Comitê Nacional Científico de Documentação do Icomos Brasil

Eliel Américo Santana da Silva

https://orcid.org/0000-0003-3566-8353 Universidade de Brasília / Brasília [DF] Brasil

Juan Carlos Guillen-Salas

https://orcid.org/0000-0002-9859-3056 Universidade de Brasília/ Brasília [DF] Brasil

Luana Miranda Esper Kallas

https://orcid.org/0000-0002-9808-0402

Universidade Federal de Goiás / Goiânia [GO] Brasil

RESUMO

Com o advento da indústria, o progresso veio com ferrovias, estações e locomotivas, símbolo da modernidade. No Brasil, esse símbolo de avanço e desenvolvimento iniciou-se em 1850 e caiu em desuso em 1970. Em Goiânia, o seu uso durou aproximadamente 30 anos e em Brasília, pouco mais de uma década, sendo reabilitada como terminal do transporte Rodoviário de passageiros, passando a se chamar Rodoferroviária. A primeira estação, em estilo arquitetônico Art Déco é patrimônio tombado desde a década de 2000 e hoje está aberta à exposição e ao atendimento da Prefeitura Municipal de Goiânia; enquanto a segunda, em estilo modernista não chegou a ser tombada, há uma intenção de tornála Museu da Ciência e Tecnologia, mas hoje, com nova reabilitação comporta alguns órgãos públicos do Governo do Distrito Federal. Nesse sentido, objetiva-se neste artigo apresentar a história e uma representação da antiga Estação Ferroviária de Goiânia e da antiga Rodoferroviária de Brasília documentada por sketches. A metodologia contempla análise de documentos de fonte primária e secundária. Como resultados, baseado no referencial teórico se identificou por meio dos sketches explicitando a materialidade, espaço, tempo e pessoas, seguida pelas cidades, e os edifícios das estações ferroviárias, seguido pelas conclusões à guisa de comparações sobre a representação e história dos objetos de estudo documentado por sketches.

PALAVRAS-CHAVE

Representação. História. Estação Ferroviária de Goiânia. Rodoferroviária de Brasília. Documentação por sketches.

\section{Representation and history of the former railway station of Goiania city [state of Goias, Brazill and the Brasilia railway station documented by sketches}

\begin{abstract}
With the advent of industry, progress came with railways, stations and locomotives, a symbol of modernity. In Brazil, this symbol of advancement and development began in 1850 and fell into disuse in 1970. In Goiania, its use lasted approximately 30 years and in Brasilia, just over a decade, being rehabilitated as a terminal for passenger road transport, renamed "Rodoferroviária". The first station, in Art Deco architectural style, has been a listed heritage site since the 2000s and is now open to exhibition and assistance from the Goiania City Hall; while the second, in a modernist style, was not listed, there is an intention to turn it into the Science and Technology Museum, but today, with a new rehabilitation, it will include some public agencies of the Federal District Government. In this sense, the objective of this article is to present the history and representation of the old Railway Station in Goiania and the old "Rodoferroviária" in Brasilia documented by sketches. The methodology includes analysis of documents from primary and secondary sources. As a result, based on the theoretical framework, it was identified through sketches explaining materiality, space, time and people, followed by cities and railway station buildings, followed by conclusions by way of comparisons on the representation and history of the objects of study documented by sketches.
\end{abstract}

\section{KEYWORDS}

Representation. History. Goiania railway station. Rodoferroviária of Brasilia. Documentation by sketches. 


\section{Introducão}

O convite para um dia de encontro entre urban sketchers nas estações ferroviárias pode nos trazer registros de nostalgias e muitas histórias, e se pudermos apreciar a música o "Trenzinho Caipira" - Bachianas Brasileiras n.2 - de Heitor Villa-Lobos, então se tornará uma memória inesquecível. Em se tratando de Brasil, em algumas cidades esse cenário demonstra um período heroico, dos grandes vãos cobertos por estruturas de ferro trabalhado e vidro, dos relógios que ainda marcam a saída e chegada tanto dentro como fora. Tempos de muitas saudades e porque não dizer na maioria das vezes, o retrato do abandono desse item do nosso patrimônio arquitetônico e urbanístico e de nossa memória.

O transporte ferroviário no Brasil perdeu sua força no início dos anos de 1970, quando a opção pelo carro e consequentemente a valorização das rodovias esvaeceu seu protagonismo valorizado no final do século XIX pelo império, início do século XX pela República e em meados do século XX durante os governos de Getúlio Vargas. Esse fenômeno também foi evidenciado em muitos países do jovem continente americano, contrariando as cidades europeias, onde muitas das estações ferroviárias foram modernizadas, não só em novas tecnologias de transportes e mobilidade, mas também em suas linguagens arquitetônicas.

Das novas construções do século XIX como hospitais, fábricas, escolas e outros, sem dúvidas as estações ferroviárias foram, certamente, as que melhor representaram o impulso para a modernidade tecnológica e econômica. Suas construções surgiram principalmente entre os anos de 1840 e 1860, com redes de integração envolvendo todo o território das principais metrópoles europeias.

Esse típico edifício do século XIX que ainda marca as cenas urbanas do velho continente e algumas vezes do Brasil, apresenta uma tipologia com duas partes distintas, a plataforma de trens e o edifício para as pessoas. A primeira diz respeito ao conhecimento da engenharia, é funcional e precisa; a segunda apresenta um diálogo constante com o campo de conhecimento da arquitetura, e muitas vezes monumental. Para Zucconi (2009) essas partes evidenciam claramente o contraste entre técnica e arte.

A plataforma ferroviária para Zucconi (2009) assume totalmente sua característica: as abóbodas metálicas se repetem sempre iguais. A sociedade industrial forneceu essa lógica estandardizada que se repetiram em várias cidades europeias e em suas colônias. A grande abóbada transparente, que parece satisfazer perfeitamente o programa de necessidades e suas funções povoa a paisagem da maioria das cidades do século XIX e se perpetuam até nossos dias.

$\mathrm{Na}$ construção análoga, o edifício para as pessoas, é diferente. Ele assume força no contexto visual urbano, com suas dimensões na maioria das vezes imponente, é tratado como outros importantes edifícios públicos, ao nível dos hospitais, bibliotecas, escolas, museus e outros.

O comportamento das estações ferroviárias nas duas das principais metrópoles culturais e econômicas da Europa, Paris e Londres, deu-se das seguintes formas: No primeiro caso, o sistema ferroviário e consecutivamente as estações urbanas nascem no mesmo período de reestruturação urbana pelo Barão Haussmann. Para Zucconi (2009), o caso de Paris, tratou-se de uma organização de raio mais amplo, as fachadas dos edifícios das pessoas enquadram novos eixos. A lógica urbana imposta por Haussmann foi contemporânea ao surgimento das redes ferroviárias no Europa, logo, o desenho da capital francesa no século XIX já contemplava o transporte ferroviário, principalmente no que diz respeito ao acesso para o subúrbio parisiense.

Esses eixos ou bulevares da Paris conectavam todos os principais monumentos arquitetônicos do início ao fim e ao longo dos mesmos, e as estações rodoviárias assumem esse perfil monumental, principalmente, quando se trata do edifício para as pessoas.

No caso de Londres, segundo Zucconi (2009), por não experimentar uma forte reestruturação urbana no século XIX, o cenário da rede ferroviária foi bem mais direcionado, resumindo, os grandes terminais ferroviários foram posicionados ao longo de artérias já existentes.

No Brasil, assim como na Europa, a ferrovia e as estações eram sinônimas de progresso. No Brasil, as ferrovias somente chegaram por iniciativa do Barão de Mauá, na década de 1850, com a construção da São Paulo Railway, sendo a primeira ferrovia do Brasil. A rede ferroviária cresce um pouco até 1890 em alguns estados brasileiros, mas é entre 1891 e 1920, que há uma expansão rumo ao sul e ao nordeste.

No entanto, foi com a Marcha para o Oeste do Brasil que, na década de 1930, houve uma intenção de ocupar, povoar, desenvolver o Centro-Oeste do país. Nesse contexto, o estado do Goiás é a região com potencial para 
o desenvolvimento econômico e se tornar o grande celeiro brasileiro, junto viria a integração, tão almejada, do país com a proposta da rede rodoferroviária unificadora (Manso, 2001).

Em 1957, com o projeto do Plano Piloto de Brasília e a mudança da capital, o grande desejo de expandir até Brasília a linha férrea que chegava até Goiânia era crucial para o desenvolvimento da Capital, pois o mesmo alimentaria com o material necessário para a construção da cidade. No entanto, a expansão chegou apenas, em 1968, até a estação Bernardo Sayão, no Núcleo Bandeirante, e mesmo que a terraplanagem no Plano Piloto já estivesse pronta, os trilhos e a estação somente ficaram prontos por volta de 1974, e as rodovias já haviam chegado, deixando o modal férreo de lado.

Esse breve histórico apresenta a importância das ferrovias e suas estações no período da industrialização, desenvolvimento e progresso, tanto na Europa, quanto no Brasil. Nesse sentido, como forma de acompanhar esse progresso, muitos mestres da pintura tentaram representar o símbolo da modernidade e da industrialização, como as ferrovias e suas estações e que se tornam registros importantes da história em forma de desenhos e pinturas, que marcam os elementos do espaço e tempo retratados.

A história é permeada por imagens para mostrar os modos de viver, costumes, arquitetura e cidade. Os artistas em cada tempo representam esses momentos, com seus estilos individuais e técnicas, que são o registro para a posteridade, mesmo com o surgimento da fotografia, o desenho e a pintura ainda são formas de registro. $\mathrm{Na}$ atualidade, movimentos de desenhistas de rua registram as mais diversas cenas do cotidiano.

É nesse contexto, de história e representação que esta pesquisa apresenta as estações ferroviárias das duas novas cidades do Centro-oeste, Goiânia e Brasilia, como objeto de estudo e que são documentadas por sketches. Dessa forma, o objetivo geral deste trabalho é apresentar a representação e história das estações ferroviárias em Goiânia e em Brasília documentada por sketches.

Dos movimentos de desenhistas de rua, os sketches desenvolvidos em Goiânia [GO] e em Brasília [DF] pela prática do desenho de observação no local pelos Urban Sketchers Brasilia [DF], no Distrito Federal e em Goiânia, pelo Goiânia em Traços, Grupo de extensão da FAV/UFG criado para valorizar e resgatar a cidade e sua arquitetura por meio de Sketches.

Este artigo está organizado pelos seguintes itens: 1. Introdução; 2. Material e Métodos; 3. Representação das estações ferroviárias pelos mestres da pintura; 4. Estações Ferroviárias do Centro-Oeste: Goiânia e Brasillia; e como resultados o item 5. Os edifícios da antiga Estação ferroviária de Goiânia e da antiga Rodoferroviária de Brasilia: representação por sketches, conhecendo a cidade e educação patrimonial; e por fim, o item 6. Conclusões.

\section{Material e Métodos}

Este artigo trata-se de uma pesquisa exploratória, pesquisa documental, pesquisa bibliográfica e pesquisa na internet, e uma produção de uma documentação contemporânea com base em observações in loco nos objetos de estudo, baseados principalmente, em períodos anteriores à pandemia.

Portanto, para este artigo como pesquisa exploratória trata de uma visão geral sobre os objetos de estudo, de acordo com Oliveira (2016, p.65) "esse tipo de pesquisa desenvolve estudos que dão uma visão geral do fato ou fenômeno estudado."

Para a pesquisa documental, foram utilizadas as informações de revistas históricas, a coletânea de 40 volumes da Revista Brasília, que compreende o primeiro documento referente à Brasília durante sua construção e disponibilizadas na biblioteca digital do Senado. Sobre Goiânia, como se trata de um bem tombado foram utilizados documentos referentes ao tombamento que subsidiam este artigo encontrados nas bases do IPHAN. Em ambas as informações se buscou a fonte histórica dos objetos de estudo. Além de anuários e leis que contribuíssem para a construção histórica do tema tratado. E o estudo das obras dos mestres da pintura que possibilitam a análise do espaço, tempo e materialidade.

Para a pesquisa bibliográfica, foram utilizados os livros que compõem na íntegra a proposição projetual das duas cidades, como base de referência para comparações realizadas nas conclusões. Teses, Dissertações, Artigos científicos e outras fontes de referência, como sites e blogs que possuem rico acervo sobre a temática ferroviária, com mais de 20 anos de atuação, todos disponibilizados na internet.

Ao final, como resultados, são apresentados materiais concernentes à produção da documentação por 
sketches dos objetos de estudo, como um tipo de documentação aparente conforme (Kallas, Guillen-Salas, \& Silva, 2020).

\section{Representaç̃o das estações ferroviárias pelos mestres da pintura}

\subsection{MATERIALIDADE, ESPAÇO, TEMPO E PESSOAS}

A materialidade dos componentes das estações ferroviárias tinha o protagonismo do ferro e do aço, principalmente em cidades do século XIX. Para Walter Benjamin (2007), seria a dedução dialética da construção em ferro, assim como todas as galerias comerciais e outras passagens da velha Paris. Logo, as estações ferroviárias trariam um novo sistema de tetos, originando novas formas de arte. Isso foi registrado por Claude Monet (Figura 1) em suas muitas viagens à Normandia e Inglaterra pela estação terminal para o nordeste da França, Saint-Lazare. Os efeitos que se infiltram no telhado de vidro impressionaram o pintor, assim como as nuvens saindo das locomotivas e dissolvendo-se no alto do grande vão da estrutura da plataforma.

Émile Zola festejou a pintura de Monet como descoberta de uma poesia da modernidade, "poesia das estações". Uma vez que, Monet tinha por costume o registro dos jardins e paisagens do campo e com sua mudança para Paris voltou a investir em paisagens urbanas.

A pintura da Estação de Saint-Lazare pertencente ao Museu d'Orsay registra não só vida urbana, mas a fase de entrega totalmente a um tema. Para desenvolver vários registros desse cenário, Monet pediu permissão em 1877 para trabalhar na estação. Um cenário ideal para busca dos efeitos de mudança de luz, movimento e nuvens de vapor, e um motivo radicalmente moderno, o interesse pelos anônimos que aparecem vagamente na pintura.

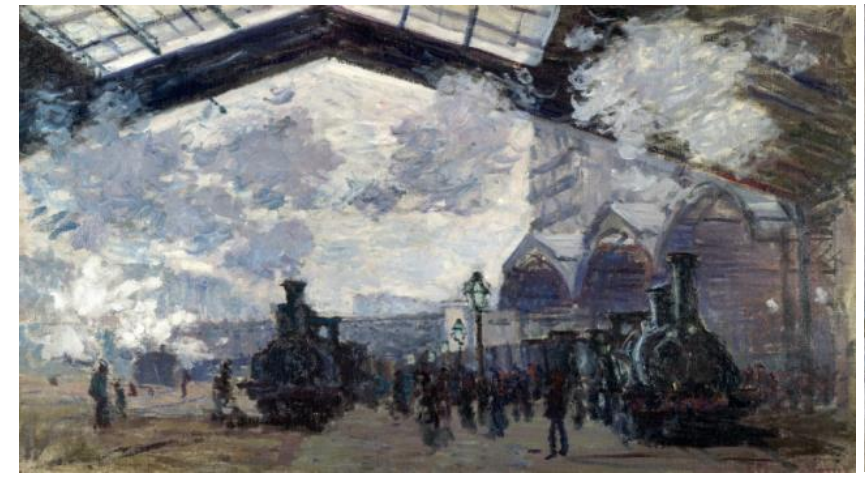

Figura 1. Claude Monet, The Gare St-Lazare, 1877. Fonte: Por Claude Monet - National Gallery, London, Domínio público, https:// commons. wikimedia.org/w/index.php?curid=30676817

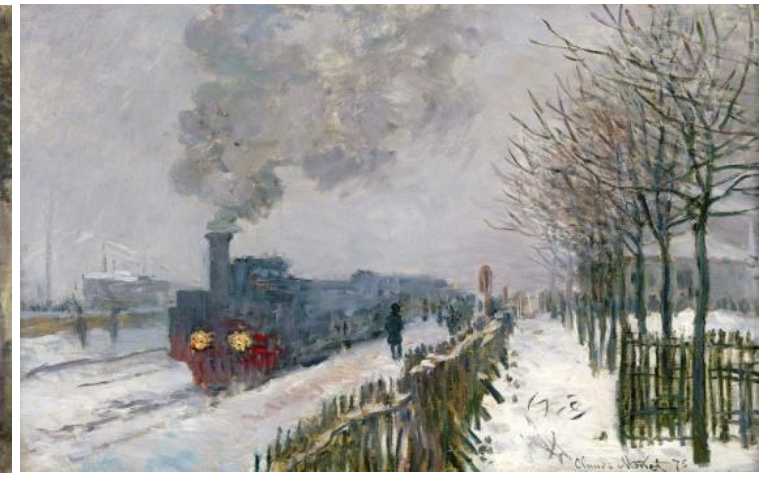

Figura 2. Trem na Neve, Claude Monet, 1875. Train in the Snow, oil on canvas, $59 \times 78 \mathrm{~cm}$, Musée Marmottan Monet. Fonte: Por Claude Monet - Here, Domínio público, https://commons.wikimedia.org/w/index.php?curid $=30347832$

Fora do ambiente interno da ferrovia, outra marcante pintura é o trem na neve do mesmo Monet em 1875 (Figura 2), dois anos antes do pintor se dedicar a observar cuidadosamente a lógica estrutural do espaço interno das estações ferroviárias. Nessa obra há exaltação do modal dos trilhos, a perspectiva em um ponto de fuga é pragmática e didática, o trem se aproxima do expectador e a paleta de cores frias tem o branco da neve como suporte da composição e um contraste em vermelho e amarelo para os faróis da locomotiva. A máquina é totalmente desfigurada, as pinceladas dialogam entre os tons de branco e azul, o registro da fumaça da locomotiva celebra novamente a modernidade.

Van Gogh registrou em Railway Carriages de 1888 a sedução pela estrutura dos vagões, por suas cores vibrantes e muito menos pelo movimento e a textura da fumaça. As cores e o protagonismo valorizado pelos vagões ao se posicionarem na linha do horizonte são marcantes nesse experimento de Van Gogh. A base da pintura representada ora por uma zona gramada ora pela terra batida marca o tema de principal abordagem do autor, as possibilidades de revolução na representação da pintura moderna a partir do landscape. Resumindo, o que mais importa é a cena do campo e sua relação com a modernidade da rede ferroviária, totalmente contrária a pintura de Monet. As bordas das cidades, o subúrbio, a ligação entre o campo e a cidade são temas a serem percebidos.

Em Landscape with carriage and train de 1890 (Figura 3), Van Gogh descreve sua obra da seguinte forma: 
Lately I've been working a lot and quickly; by doing so I'm trying to express the desperately swift passage of things in modern life. Yesterday in the rain I painted a large landscape viewed from a height in which there are fields as far as the eye can see, different types of greenery, a dark green field of potatoes, between the regular plants the lush, violet earth, a field of peas in flower whitening to the side, a field of pink-flowered lucerne with a small figure of a reaper, a field of long, ripe grass, fawn in bue, then wheatfields, poplars, a last line of blue hills on the horizon, at the bottom of which a train is passing, leaving behind it an immense trail of white smoke in the greenery. A white road crosses the canvas. On the road a little carriage and white houses with stark red roofs beside this road. Fine rain streaks the whole with blue or grey lines (Van Gogh, 1890).

Apesar da referência em relação a "modern life" ou na tradução para o português "a vida moderna", o landscape representado pela grande plantação é o tema abordado ao dominar $80 \%$ da composição. A linha do horizonte próxima a parte superior da moldura é enfatizada pela fumaça e discretamente pela locomotiva e seus vagões que se misturam ao azul do céu, essa linha é reforçada por paletas de tons verdes que no céu temperam-se com o azul e no chão com o amarelo.

No caso da pintura Rain, steam and speed - The Great West Railway de William Turner de 1844 (Figura 4), vapor e o fumo da locomotiva lutam contra a força da chuva. Na cena, o comboio atravessa a ponte do Rio Tâmisa, em Maidenhead, numa paisagem brumosa, num jogo sutil em que pintor sugere um campo cultivável e uma cidade ao longe. A perspectiva central revela discretamente a locomotiva negra em seu estado desmaterializado pela velocidade, vapor e chuva. A escala indetectável e sublime expressa nesta pintura e na própria linguagem das obras de Turner não deixa o pintor fora de seu tempo, um tempo da inspiração e orgulho causados pela ferrovia.

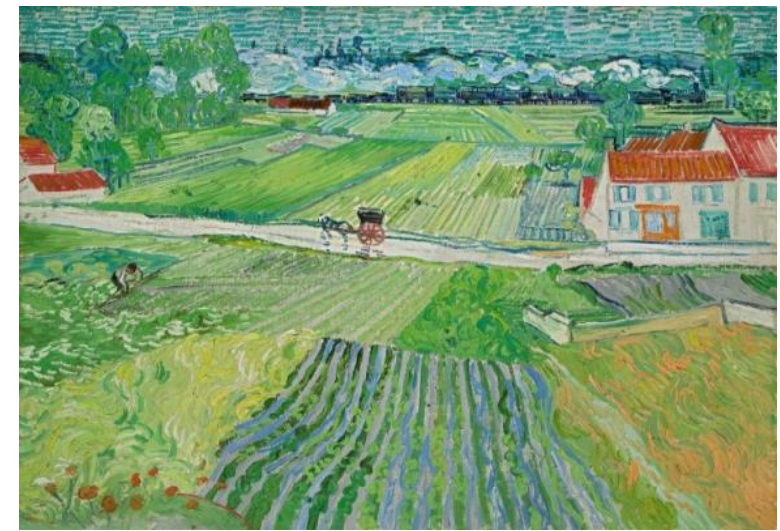

Figura 3. Van Gogh Landscape with carriage and train, 1890. Fonte: By Vincent van Gogh -

http://uploads7.wikipaintings.org/images/vincent-vangogh/landscape-with-carriage-and-train-1890.jpg Domínio público,

https:// commons.wikimedia.org/w/index.php?curid=31182386

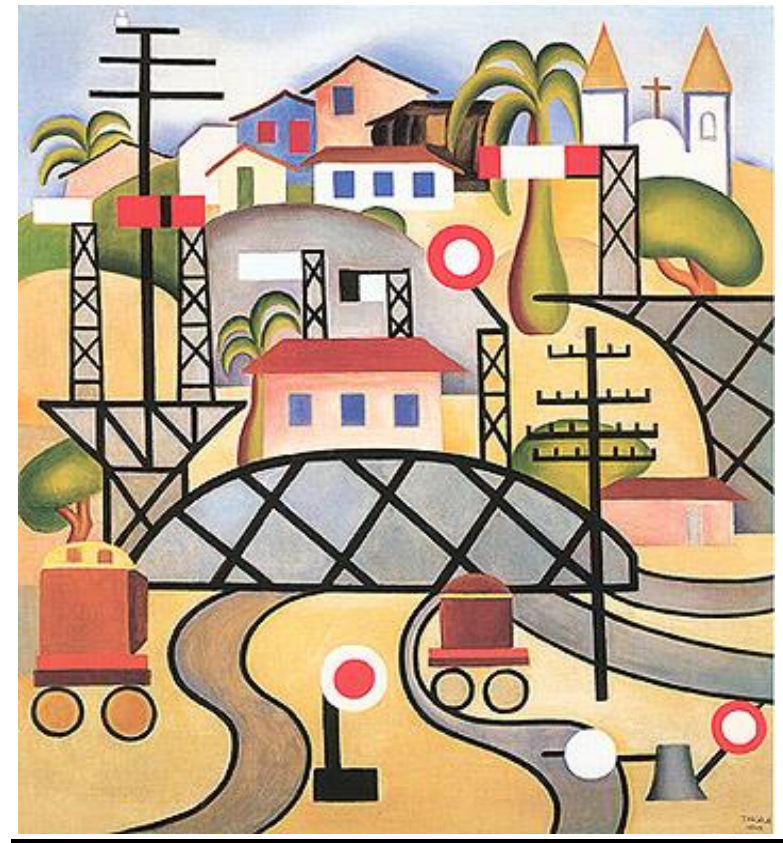

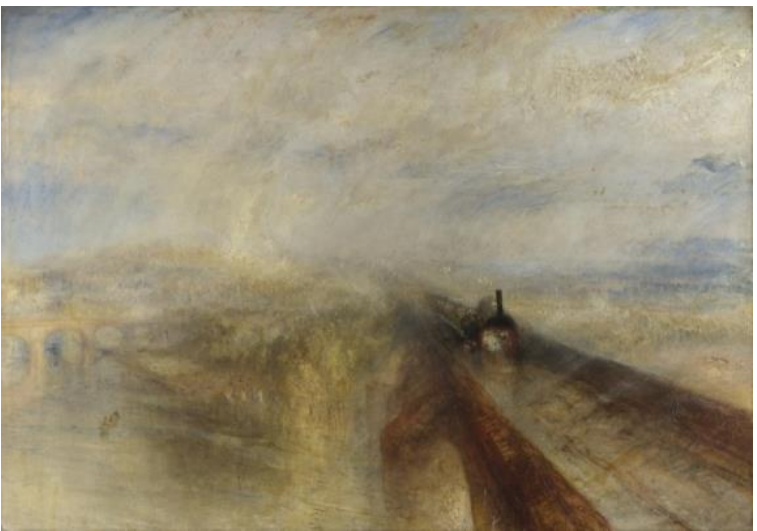

Figura 4. Turner - Rain, Steam and Speed - National Gallery file

Fonte: By William Turner - National Gallery, London, Domínio público,

https://commons.wikimedia.org/w/index.php?curid $=2230$ 3273

Em alguns registros principalmente os datados no início do século XX, como nas pinturas abstratas dos futuristas italianos Vittorio Corona e Giacomo Balla, a abordagem concentra-se na locomotiva como máquina e sua velocidade traduzida por uma linguagem abstrata e geométrica.

Tardiamente em 1924, Tarsila do Amaral uma das pioneiras da Semana de Arte Moderna em 1922, desenvolve a pintura Estrada de Ferro Central do Brasil (Figura 5). Postes de luz elétrica, vagões de locomotivas, sinalizações de ferrovias, pontes e torres de ferro, vazios urbanos, casas e janelas são resolvidos na linguagem abstrata e geométrica, embora, estática e elementar, diferente dos futuristas italianos.

Figura 5. Estrada de Ferro Central do Brasil, por Tarsila do Amaral. Fonte: Estrada (2021). 
Se analisarmos as partes espaciais que compuseram no século XIX as estações ferroviárias, a plataforma funcional e operacional, principalmente, para os artistas do século XIX foi a mais registrada, ou na cobertura de ferro envolvendo as locomotivas e suas fumaças por Monet ou no sistema de trilhos, locomotivas, comboios e paisagem visualizados e retratados por Van Gogh, Turner, Corona, Balla e Tarsila.

Entretanto, alguns artistas nesse período também registraram o corpo, gestos e feições que davam escala a essa plataforma. Tratava-se dos viajantes, das pessoas que compuseram esse século XIX e início do século XX nos seus passos, em pé ou sentados dentro dos comboios.

As estações ferroviárias tiveram um papel fundamental nas principais metrópoles europeias nesse período. Fundaram cidades, centralizaram a vida das comunidades, serviram de agência de correios, telégrafos, restaurantes, cafés e muitas vezes locais de trabalhos para autônomos que necessitavam de seu sustento. Agora sem dúvidas, a facilidade de mobilidade entre os territórios que esse sistema de transporte favoreceu, aproximou não só corpos, como raças e porque não dizer classes sociais.

No interior dos vagões de viagem e comboios, rostos cansados depois de uma jornada de trabalho, expressões caricatas e seres humanos em suas "imperfeições" algo que a escola de belas artes recusava retratar, registrados ou por desenhos ou por pinturas. As pessoas como elas são, a não nobreza, o povo pós-industrial.

Honoré Daumier foi a grande expressão desse tema. Na pintura Vagão de terceira classe de 1962 (ver Figura 6), capturou os efeitos da industrialização da capital francesa. Viagens de trem foram frequentes em suas obras, esse quadro é incompleto e compõe uma série de três ilustrações da vida sofrida dos viajantes. Os contemporâneos de Daumier como Van Gogh, Gauguin, Milet, Toulouse Lautrec e outros admiravam a universalidade desse tema de retratação das imperfeições, miséria, alegrias e tormentos de uma população que graças a mobilidade ferroviária invadiu o centro urbano burguês parisiense.

Daumier foi um grande caricaturista parisiense, zombava do seu próprio tempo, captou o típico e patético burguês francês, assim como, uma caricatura do Rei Luís Felipe I chamada “Gargântua", em 1832, retratado como um monstro devorando seus súditos e sacos de ouros, o que o levou a prisão por seis meses. Le wagon de troisième classe ( $\mathrm{O}$ vagão de terceira classe) mostrou a compaixão pela população que utiliza os trens, os menos favorecidos. A utilização desses temas do cotidiano, que levaram a discussão sobre as questões sociais mais amplas, fizeram de Daumier, mesmo depois da prisão, um dos artistas mais admirados e respeitados não só por colegas de trabalho, como também pela população parisiense.

Para Edward Hopper, um típico artista do século XX, a modernidade representada por locomotivas ou estações de trem não foi o tema dominante, a ele interessava a solidão que a sociedade moderna causava. Sua linguagem realista da vida americana do pós-guerra introduzia corpos silenciosos e solitários em lanchonetes, motéis de estradas, estações de gasolinas, ruas vazias e estações ferroviárias. American Locomotive de 1944 representa uma deslumbrante locomotiva moderna vermelha e, no primeiro plano, pai e filho contemplando essa representação da modernidade.

Arquitetura e espaços, ruas realistas em sua abordagem servem de uma atmosfera intrinsicamente ligada ao sentimento traduzido nos personagens de Hooper. Nesse momento, ele se compara a Honorè Daumier, na representação do tema corpos, americanos típicos, pouco caricatos, mas solitários. Uma moça de chapéu, muito bem vestida, concentrada em sua leitura totalmente envolta a uma cabine de trem em tons verdes e uma paisagem fugaz numa paleta de cores complementares; a mesma atmosfera de angustia e solidão é notada na gravura a lápis "Noite no Trem" no início de sua carreira no ano de 1918 (Figura 7), um casal a namorar ou conversar intimamente de forma tensa num vagão vazio em um longo banco estofado.

Hopper da mesma forma que Daumier, embora criando um cenário espacial contundente, explora o cidadão comum, com menos senso de humor que o artista francês, mas tendo a angústia e a solidão como temperos necessários a suas experiências. Essas personagens povoam as estações rodoviárias e fazem parte o desenho da cidade, são pessoas que caminham nesses espaços, anônimos que atravessam o tempo na utilização dos espaços públicos, nos espaços da mobilidade urbana e coletiva.

Embora Monet, Van Gogh, Balla e outros muitos mais motivados por seu tempo, preferissem o registro da modernidade representada na fumaça, na cobertura da plataforma ou na velocidade, as pessoas que utilizavam a plataforma, a estação ou o comboio tiveram seu destaque ainda nas pinturas do século XIX e início do século XX. 


\section{Labor \& Engenho}

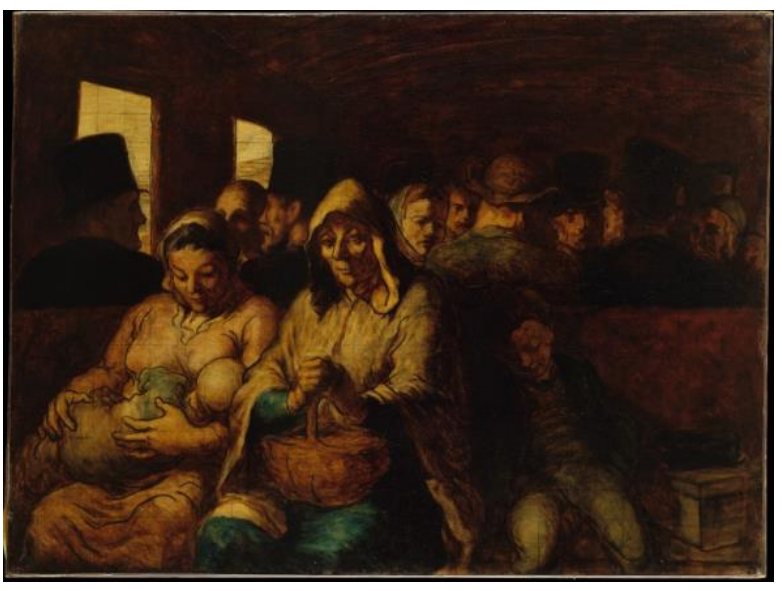

Figura 6. The Third-class Carriage - Honoré Daumier. Fonte: Por Honoré Daumier - Este ficheiro foi doado ao Wikimedia Commons por como parte de um projeto do Metropolitan Museum of Art. Veja a Política de Acesso Aberto a Imagens e Dados (em inglês). Domínio público, https:// commons. wikimedia.org/w/index.php?curid=30139434

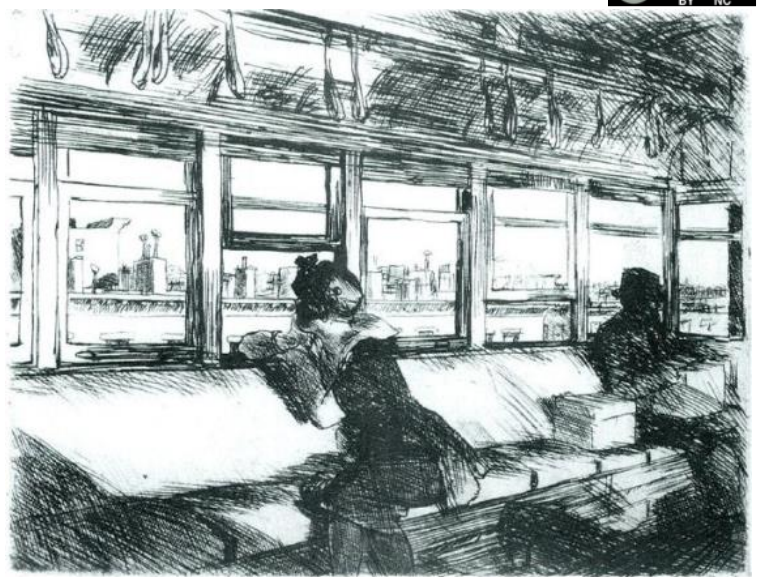

Figura 7. Night on the El Train, 1918.

Fonte: By Edward Hopper - Berman, Avis. Edward Hopper, New York. San Francisco: Chameleon Books, Inc., (2005).

Public Domain,

https://commons.wikimedia.org/w/index.php?curid=10390145

\subsection{CIDADES, EdIFÍCIOS E ESTACÕ̃ES FERROVIÁRIAS}

Poucas foram as representações em pinturas e desenhos da arquitetura e sua relação com a cidade tanto da plataforma quanto dos edifícios das pessoas, parece que o interesse nesse tema não despertou tanto nos artistas do século XIX e de nossa contemporaneidade, e não foi por falta de desenhos urbanos que inspirassem para tal.

A Paris de Haussmann serviu de inspiração na relação entre eixos urbanos e equipamentos ferroviários, anteriormente já explicitado, muitos projetos de cidades que ficaram no papel - e muitos executados - tiveram no desenho de Paris a provável relação entre a estação ferroviária como marco visual e o espaço urbano, ora implantadas ao longo das vias ou bulevares, ora marcando início e fim dos mesmos (Zucconi, 2009).

No desenho intitulado La Città Nuova de 1914 (Figura 8), Antonio Sant'Elia propõe sua estação ferroviária como um complexo verticalizado com funções mistas de escritórios a pequenos apartamentos de moradias, estabelecendo layers das principais fontes de mobilidade e velocidade da era industrial. Estação de trem, aeroporto, vias para automóveis e pedestres compõe um espaço monumental que abriga predominantemente a circulação de pessoas ou viajantes na linguagem arquitetônica art decó da escola de Viena e de um de seus principais inspiradores, o arquiteto Otto Wagner.

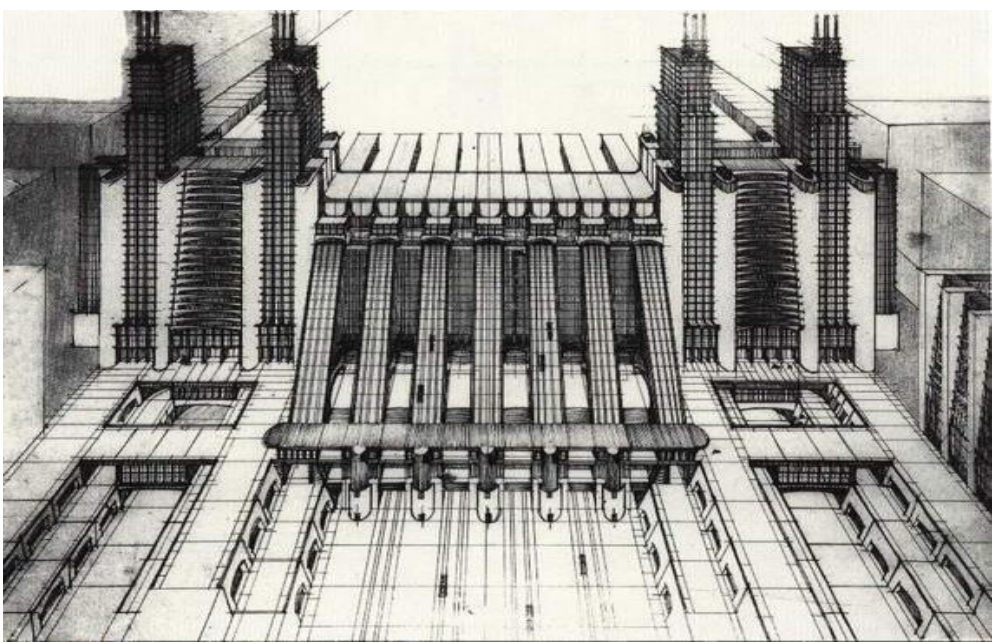

Figura 8. La città nuova, 1914 - autoria Antonio Sant'Elia Fonte: Por Antonio Sant'Elia - from La città nuova. Domínio público, https://commons.wikimedia.org/w/index.php?curid=226056
Na década de 1930 surge no centro do país a capital do estado de Goiás, Goiânia, o desenho assinado pelo urbanista Atílio Corrêa Lima teve influências, de Versalhes e Washington, embora, os bulevares de Haussmann e a linguagem futurista e Art Déco de Antonio Sant'Elia permearam sobre as concepção de Atílio Corrêa Lima, principalmente no que se refere a um dos mais enigmáticos prédios de Goiânia, a Estação Ferroviária

O projeto de Goiânia é importante no que diz respeito ao protagonismo da estação ferroviária, não como um edifício de limite do perímetro urbano, mas um marco visual na composição urbana. Juntamente com a Central do Brasil, no Rio de Janeiro, com a inauguração em 1858 com os nomes de Estação do Campo, Estação da Corte, Estação Dom Pedro II e por fim Estação Central do Brasil e a Estação Mairinque do Arquiteto Victor 
Dubugras de 1877, a Estação Ferroviária da nova capital de Goiás simboliza um dos mais importantes projetos desse equipamento tão importante para o século XIX.

A importância das ferrovias é que elas ultrapassam o marco visual e se perpetuam na memória da cidade como discutido por Kallas, Guillen-Salas e Silva (2020). Em Goiânia, a ferrovia se perpetua como um marco visual, mas também por meio de nomes em alguns de seus bairros, como Setor Norte Ferroviário e Setor Norte Ferroviário II, lindeiros à Estação Ferroviária e em outros lugares da cidade, como designação de Ruas em alguns bairros/setores, como Rua dos Ferroviários no Setor Norte Ferroviário; no bairro Esplanada dos Anicuns, a Rua dos Ferroviários que segue até o bairro Industrial Mooca; no bairro Parque Industrial João Bras, mais referências, além da Rua dos Ferroviários que na sequência se torna Rua Estrada de Ferro e que encontram com a Rua da Estação.

Sua monumentalidade finaliza o eixo da Avenida Goiás com início na Praça Cívica passando pelo Coreto e o Relógio, todas preciosidades desse conjunto arquitetônico Art Déco brasileiro. Esse eixo conceitual que define e organiza o projeto original de Atílio Corrêa Lima, sem dúvidas, influenciará projetos de outras capitais brasileiras, sendo a mais importante, Brasília.

Lucio Costa, vencedor do concurso de 1957 para Plano Piloto de Brasília, teve referências fortes em projetos de cidades capitais e Goiânia foi uma delas. O eixo leste - oeste, Eixo Monumental, que abriga os principais monumentos da capital, tem seu início na Praça dos Três Poderes e finaliza na Estação Ferroviária, mais tarde transformada em Rodoferroviária de Brasília. Sem dúvidas, Goiânia foi sua inspiração no que concerne a composição urbana do eixo linear leste e oeste. Embora, o urbanista de Brasília não tenha detalhado sua estação ferroviária, assim como fez com a Praça dos Três Poderes, admitiu a importância desse equipamento para estrutura da Capital Nacional.

A estação ferroviária povoou desde o século XIX os programas de necessidades de todos os projetos de cidades pelo mundo. As várias propostas para nova capital brasileira desde muito antes do concurso de 1957 já tinha a estação ferroviária como ponto importante na articulação espacial, confirmado na proposta de diplomação para nova capital brasileira em 1945, por Carmem Portinho, na capital Vera Cruz de 1955 elaborada pelo engenheiro Raul Penna e até mesmo nos projetos concorrentes ao projeto de Lucio Costa.

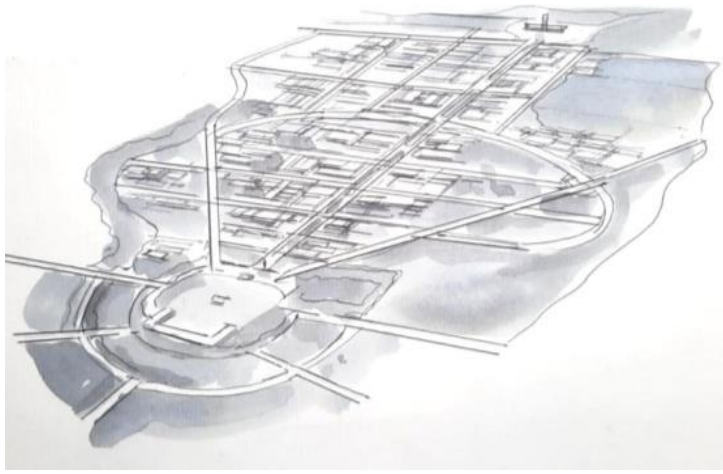

Figura 9. Desenho esquemático da parte Central de Goiânia [GO]. Desenho: Eliel Américo, 2021.

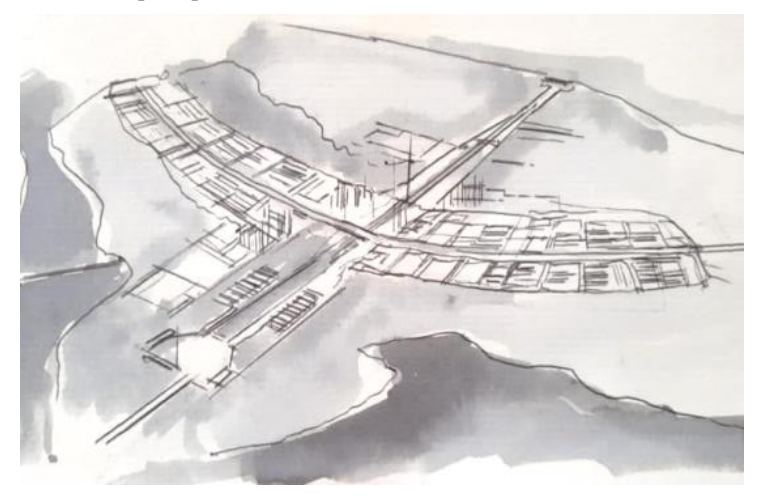

Figura 10. Desenho esquemático do Plano Piloto de Brasília [DF]. Desenho: Eliel Américo, 2021.
A Figura 9 apresenta um trecho do desenho original de Goiânia, proposição de Attílio Corrêa Lima, onde na parte inferior (Sul) encontra-se o centro administrativo da cidade e no seu extremo oposto (Norte), na parte superior da imagem, encontra-se a Estação Ferroviária da Cidade (Figura 9.)

Da mesma forma, a posição da Estação se apresenta em relação ao desenho de Brasilia, na parte inferior (Leste) o centro administrativo do país e em seu extremo oposto (Oeste), a Rodoferroviária, na parte superior do desenho (Figura 10). As propostas das duas cidades seguem a escola francesa.

O sistema ferroviário brasileiro principalmente durante o Império e início da República foi a tradução da integração entre centros urbanos brasileiros do litoral ao Planalto Central. Isso foi confirmado no concurso para o Plano Piloto de 1957, quando o termo de referência fundamentado pelo Relatório Crulz já previa a existência do sistema ferroviário, tendo a oeste a localização da estação central. Nas propostas concorrentes, inclusive a vencedora, a ferrovia seria o vetor de expansão da nova capital a partir da construção das cidades satélites (Silva, 2012).

De acordo com o Instituto Brasileiro de Geografia e Estatística (IBGE) (1954), o sistema ferroviário brasileiro 
se dividiu em 5 etapas no primeiro centenário. Segundo Brandão (2016), a linha Férrea que levava à Brasília somente surgiu em 1968, sendo concluída em 1978. Rumo ao Centro-oeste, os trilhos saiam de Araguari [MG] sentido Anápolis [GO], com 392,4 km e com a criação de Goiânia [GO], a nova capital do Estado de Goiás, um ramal foi construído partindo de Leopoldo de Bulhões (que está na linha Araguari-Anápolis) e possui $91 \mathrm{~km}$, criada em 1950. No caso de Brasília, a linha férrea somente chegou em 1968, saindo da estação Roncador, em Goiás passando pela Estação Bernado Sayão, a primeira estação de Brasília, que se localiza no Núcleo Bandeirante e depois, seguiu para o Plano Piloto.

O projeto segundo colocado, pertencente a equipe de Boruch Milman, propôs um sistema em malha a partir da estação ferroviária que direcionaria as cidades-satélites no sentido norte e sul a partir de oeste do território do Distrito Federal. Aliás, a grande maioria seguiu essa mesma lógica, inclusive o projeto vencedor. Entretanto, Lucio Costa não só entende a estação ferroviária como vetor de interiorização do Brasil, mas também, ponto focal e marco visual urbanos, repetindo a mesma experiência de Attílio Corrêa Lima, em Goiânia, no modelo das beanty cities do século XIX, dando a estação ferroviária um relativo protagonismo, numa intensidade menor se comparada a Estação Ferroviária de Goiânia (Silva, 2012).

Esses marcos urbanos deixaram de ser os protagonistas na locomoção entre cidades, sendo substituídos pela política rodoviarista, apesar disso ele continuam a marcar pontos notórios da cidade. Um emblema, um símbolo, e para alguns marcado na memória.

\subsection{DESENHO DE ESTAÇÕES FERROVIÁRIAS}

Algumas cidades guardam suas locomotivas às vezes em parques, praças e outras em canteiros centrais de ruas e avenidas, objetos de exposições, resquícios de um tempo urbano. Outras convivem com locomotivas modernizadas e inseridas em sua vida urbana ativa, na correria do dia a dia das estações (ver Figuras 11, 12, $13,14,15$ e 16$)$.

$\mathrm{Na}$ cidade de Araraquara [SP] a estação virou museu com seu relógio em ferro fundido ainda marcando o tempo ou suas locomotivas como sucatas atraentes. Em Belém do Pará, os cartões postais do início do século XX guardam o registro de um tempo glorioso da Estrada de Ferro Belém-Bragança e trilhos ainda presentes nas avenidas para confirmar esse tempo. Em Brasilia, a Rodoferroviária, hoje transformada na sede de um órgão do governo do Distrito Federal, ainda guarda seus trilhos e comboios de ferro. Em Goiânia, a estação ferroviária hoje funciona como sede de órgãos da prefeitura e espaço de exposições, e se apresenta como um dos cartões postais da cidade.

Mas no geral, em se tratando de Brasil, estação ferroviária é sinônimo de um passado que poderia vingar, de abandono, nostalgia e de viagens só vistas em filmes estrangeiros.

As expressões registradas nos desenhos de Daumier e Hopper ainda continuam após quase dois séculos no jovial sistema de metrô, difundidos praticamente em todas as grandes capitais do mundo. São as mesmas expressões de gerações de corpos que utilizaram a plataforma ou o edifício para as pessoas. Desenhar pessoas no metrô tem sido uma prática contemporânea dos urban sketchers. O movimento dos corpos, as expressões, os gestos e posições continuam a atrair desenhistas para as estações, plataformas e vagões dos metrôs. Bisnetos mais próximos das antigas estações ferroviárias, embora, as viagens sejam mais próximas, as velocidades mais rápidas e despedidas não muito sofridas, os metrôs agora recebem a nova geração inspiradas nos artistas do passado.

O Brasil optou pelas rodovias. Entretanto, temos registros de um país que poderia ter outro rumo ou outras estradas, muitas delas abandonadas, um patrimônio a ser registrado. Algumas estações como Silveira do Sal em Ribeirão Preto [SP] (Figura 17), Santa Ernestina em Santa Ernestina [SP] (Figura 18), Matão [SP], Remédios em Anhembi [SP], Mairinque em São Paulo [SP] (Figura 19), Serra Azul e muitas outras encontram-se abandonadas. Outras foram restauradas e servem a outras atividades como a Estação da Luz em São Paulo [SP], Estação Juparanã no Rio de Janeiro [RJ], Estação Ferroviária de Goiânia, em Goiânia [GO] e outras.

Mas além de todo esse investimento e trabalho na recuperação da história do transporte sobre trilho no Brasil, os grupos de urban sketchers Nacionais e regionais podem contribuir nessas ações a partir de seus desenhos e pinturas. A arquitetura da época, as locomotivas, as cidades que nasceram com as estações, os trilhos, as sinalizações, as sucatas que ficaram pelo caminho, os velhos relógios necessários no controle do tempo, todos esperando para tornarem-se documentos. 


\section{Labor \& Engenho}

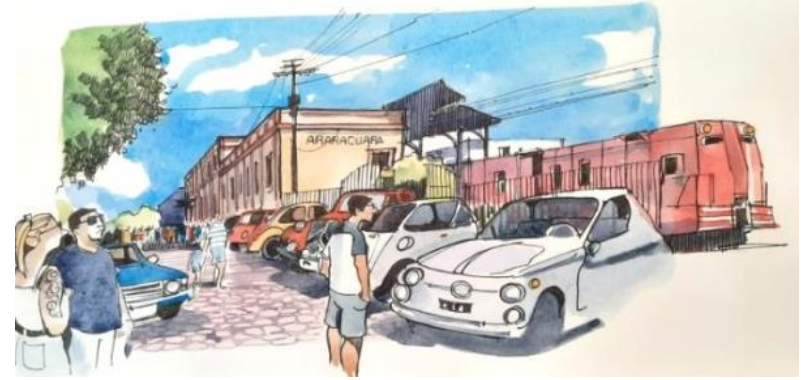

Figura 11. Estação de Araraquara [SP].

Desenho: Silva, 2021.

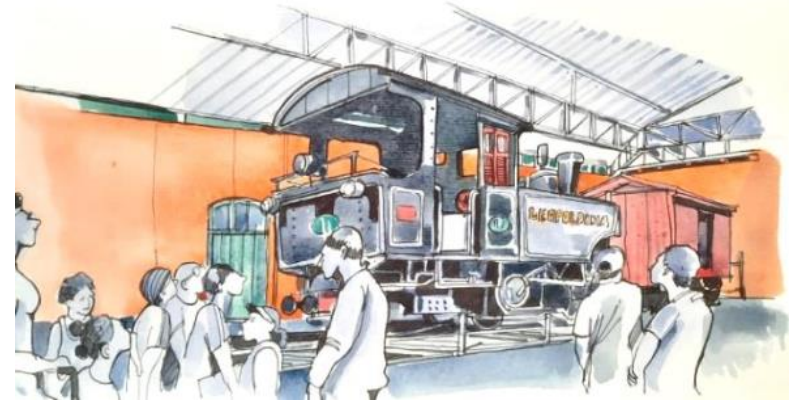

Figura13. Estação Ferroviária de Petrópolis [RJ].

Desenho: Silva, 2021.

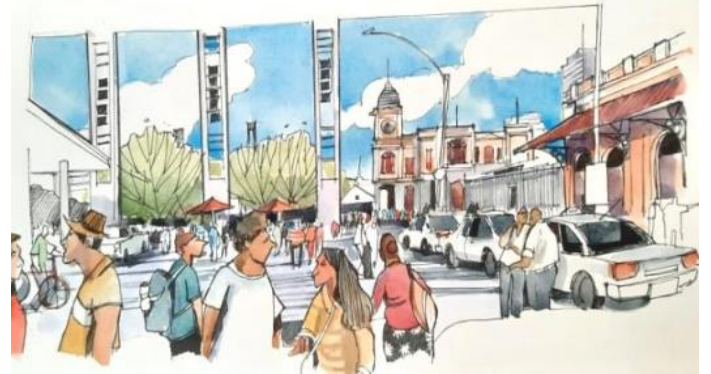

Figura 12. Estação Ferroviária de Belo Horizonte [MG]. Desenho: Silva, 2021

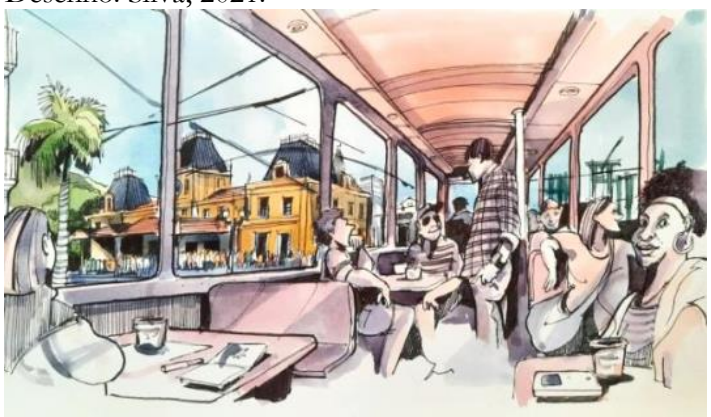

Figura 14. Estação Ferroviária de Santos [SP].

Desenho: Silva, 2021.

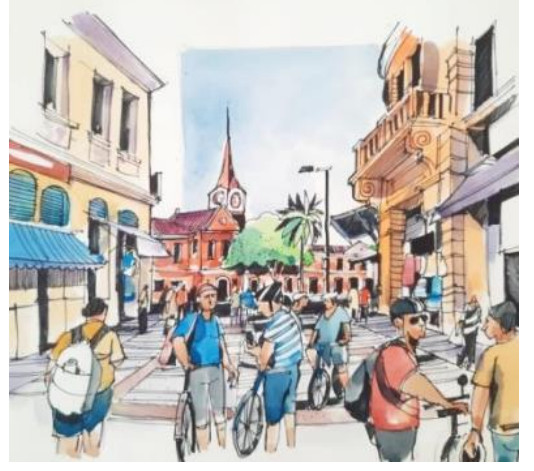

Figura 15. Estação Ferroviária de Campinas [SP].

Desenho: Silva, 2021.

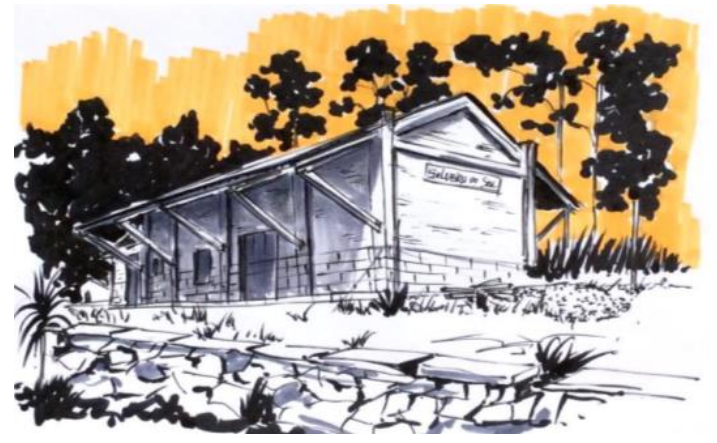

Figura 17. Estação de Silveira do Sal, em Ribeirão Preto [SP]. Abandonada. Desenho: Kallas, 2021.

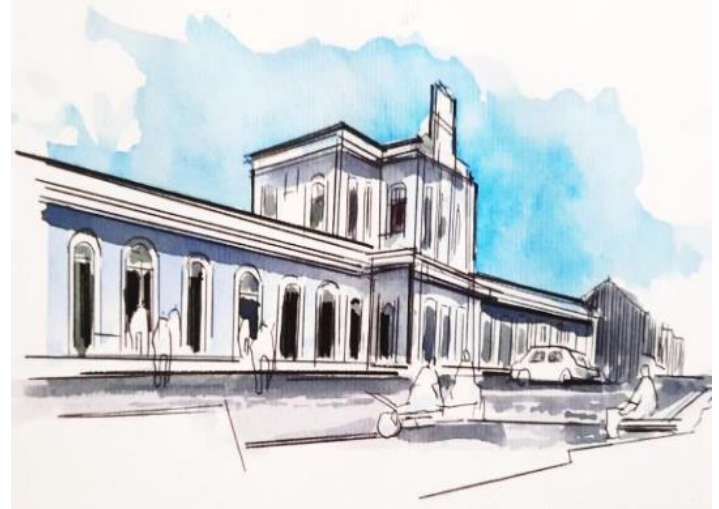

Figura 16. Estação de Belém [PA]. Desenho: Silva, 2021.

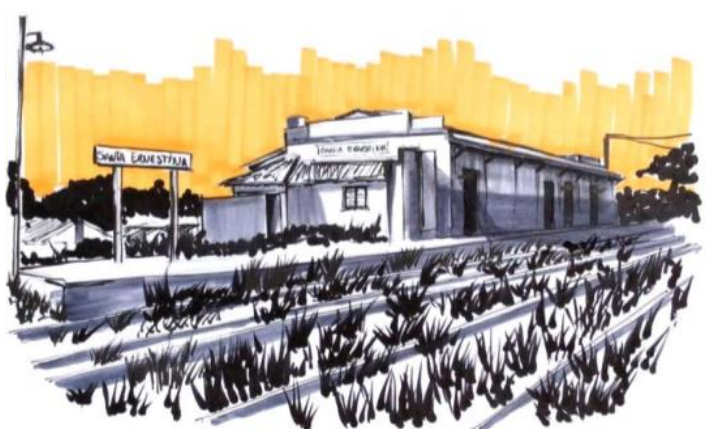

Figura 18. Estação de Santa Ernestina, em Santa

Ernestina [SP]. Abandonada. Desenho: Kallas, 2021.

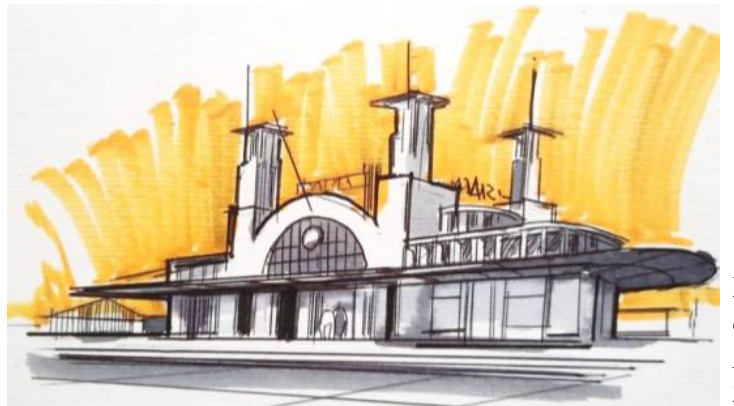

Figura 19. Estação Ferroviária de Mairinque, em Mairinque [SP]. Abandonada. Desenho: Silva, 2021. 


\section{Estacõos ferroviárias do Centro-oeste: Goiânia e Brasília}

\subsection{ESTAÇÃO FERROVIÁRIA DE GOIÂNIA}

A ideia mudancista alcançou algumas capitais estaduais, como em Goiás, talvez pela possibilidade de a nova capital de Goiás pudesse a vir ser considerada a abrigar a sede do país, como Capital Federal, devido a sua localização. Ideia essa que pode ter passado pela cabeça do interventor de Goiás, colocado por Getúlio Vargas após o Golpe de 1930, o médico Pedro Ludovico Teixeira.

Mas a ideia principal do interventor era mudar a atual capital Vila Boa de Goiás (atual Cidade de Goiás) para outra área a fim de aumentar a produção econômica e, ao mesmo tempo, uma alternativa de ligar o CentroOeste ao Sul do País, como descreve (Goiânia, s/d), pois de acordo com Coelho e Valva (2018, pp.102-103) “[...]185 quilômetros separam a velha capital da última estação da estrada de ferro, é vencida por automóvel, contudo no período das chuvas este meio de comunicação é praticamente inexistente."

Ao que parece a antiga Capital dificultava o estabelecimento de relações comerciais com outras localidades do estado e o sul do País devido a sua pouca acessibilidade, e de acordo com Manso (2001), a Política do Getúlio Vargas com a "Marcha para o Oeste" e a proposição do futuro celeiro do país localizado no centro do Brasil haveria a necessidade de modernização da capital goiana a fim de representar a nova Pátria, que Getúlio Vargas almejava.

Para a nova localização da Capital goiana, Coelho e Valva (2018) apresentaram relatórios da Comissão designada pelo interventor Pedro Ludovico, a fim de escolher a cidade que sediaria a nova Capital, apesar da resistência Vilaboense para tal mudança, a capital goiana mudou. Para isso Pedro Ludovico estabeleceu a comissão para avaliação de quatro lugares no estado de Goiás, as cidades de Bonfim, Pires do Rio, Ubatan e Campinas, e de acordo com Manso (2001, p.67) o local para a nova capital goiana deveria ser "próximo da estrada de ferro" A partir dessa comissão, uma subcomissão foi formada a fim de realizar estudos in loco e assim designar o novo lugar por meio da legitimação tecnicista.

Das quatro cidades, Campinas foi escolhida, com uma ocupação próxima à Serrinha. Nesse caso, as demais cidades, Ubatan (atual Orizona) e Pires do Rio foram descartadas inicalmente. A primeira, não era favorável a construção da Nova Capital, por não possuir elevação para a Caixa d'agua, sendo, portanto, sua construção, dispendiosa. Na segunda, a impossibilidade era que o melhor lugar para a nova Capital já estava ocupado pela sede administrativa de Pires do Rio. No parecer final, a escolha ficou entre Campinas e Bomfim, sendo Campinas a mais propensa, e na sua impossibilidade, Bomfim seria indicada, pois essa cidade teria capacidade para captação de água potável para manter a cidade, com menor custo. Mas no final, Campinas foi escolhida por ser mais cêntrica e por ter uma capacidade hídrica e de abastecimento por gravidade, que mesmo em período de estiagem, a cidade seria abastecida sem prejuízos (Coellho \& Valva, 2018).

Manso (2001, p.69) observa que apesar do relatório ter sido aprovado apontando Campinas, como a cidade escolhida para a nova capital goiana, houve posições contrárias, para que a nova capital se localizasse próximo a estrada de ferro, manter o traçado original, mas que entre a “década de 1939 a 1949" passou a ser cogitada a mudança do traçado.

Nesse sentido, Campinas tinha uma curta distância até a linha férrea, entre outras condições que fez do local o escolhido para a nova capital Goiana. E uma nova etapa para concepção do traçado urbano da cidade começa, com a introdução do Arquiteto Attílio Correa Lima até 1935, com trabalho continuado por Armando de Godoy a partir de 1935.

A proposta de Goiânia tem uma concepção inicial francesa, devido a formação de Attílio Correa Lima, com 3 vias que confluem para a Praça Cívica, o centro administrativo da cidade. Na via central (Avenida Goiás), larga e com canteiro central arborizado, como os bulevares da Paris de Haussman, que leva a parte industrial e onde se encontra a estação ferroviária (Figura 20). A ideia inicial apontada por Manso (2001, p. 101) é que a cidade pudesse crescer ao longo da via de trens.

De acordo com Guimarães (2019, p. 72-73), a cidade de Goiânia não contou logo de início com a linha férrea, sendo precedida por um campo de aviação, apesar de idealizado desde o princípio no plano de Attílio Correa Lima. Brandão (2016) e Silva (2019, p.92) corroboram que somente em 1950 é que os trilhos ferroviários chegam à Goiânia. 
Apesar de a cidade ter crescido ao longo da linha férrea, mais para o sentido Oeste, apesar da linha estar presente à leste. Porém, hoje, não há mais resquícios aparentes dessa linha férrea, que estava visível na Rua 13-A e Rua 250 do Setor Nova Vila até 2019, quando deu lugar a construção do novo viaduto à leste da estação ferroviária que liga à Região da 44 com o Setor Nova Vila, próximo à agropecuária, com consequente remodelação viária, agora Avenida Leste Oeste.

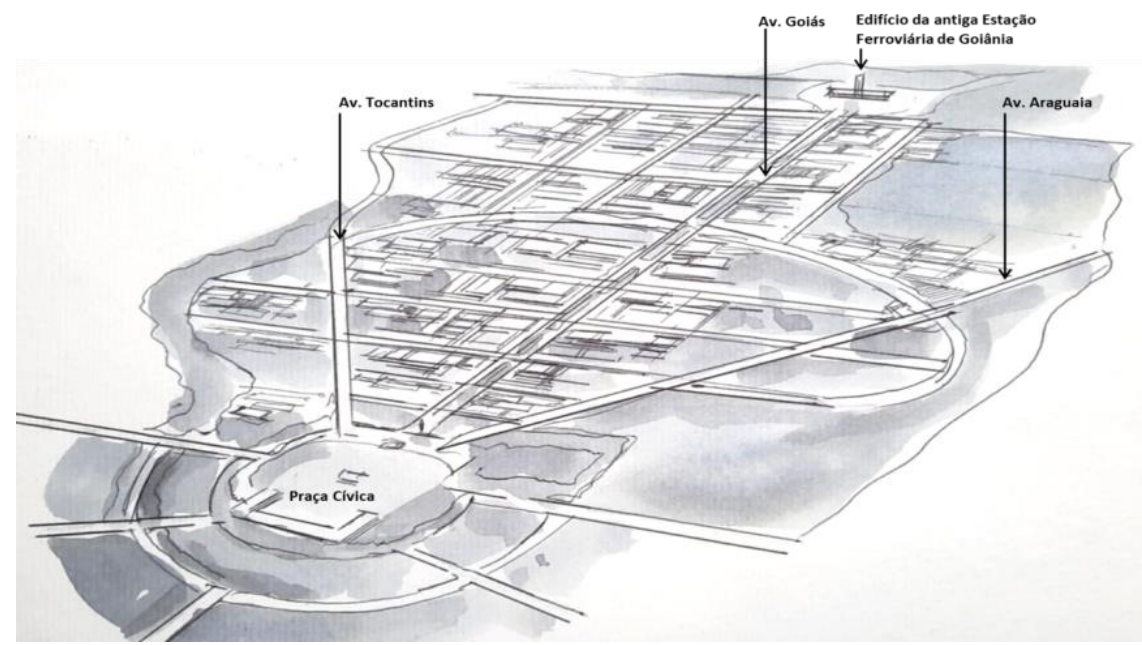

Figura 20. Esquema da concepção de Goiânia de Attílio Correa Lima. Desenho: Silva, 2021.

O edifício da antiga Estação Ferroviária em Goiânia, devido ao seu valor histórico, cultural e arquitetônico é trombando em três níveis: Federal, Estadual e Municipal, mas o tombamento não contempla o traçado viário em toda sua volta, e por isso a Praça onde se insere a Estação já sofreu bastantes intervenções. Porém a área de inserção do Edifício da antiga Estação Ferroviária de Goiânia (em vermelho) na Figura 21, possui uma delimitação do perímetro da área do entorno do bem tombado, uma subárea de ambientação, e uma subárea com restrições de ocupação, o que permite as diversas alterações do entorno imediato ao bem tombado.

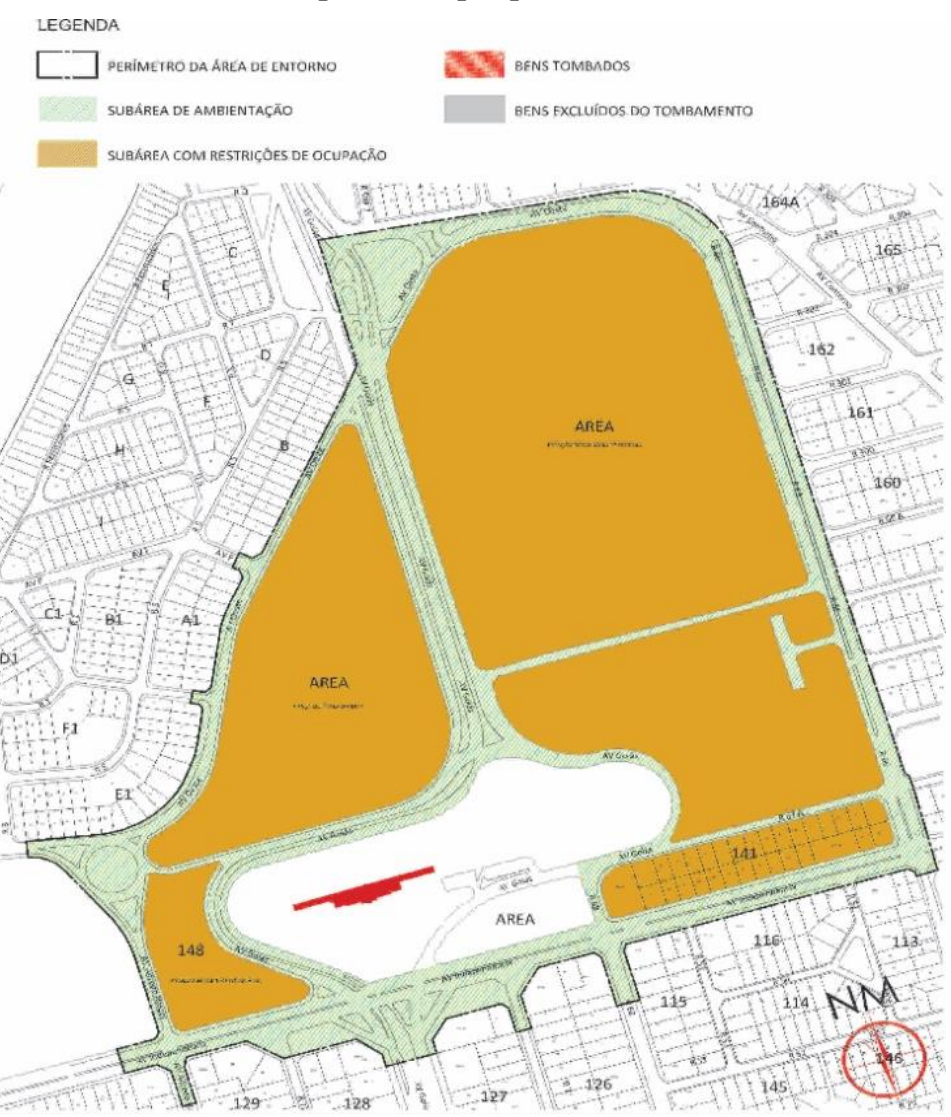

SITUAÇÁO E ENTORNO - ESTAÇĀO FERROVIARIA
A Praça do Trabalhador envolve o edifício da antiga Estação e já passou por algumas intervenções. Já possuiu um monumento em formato circular e espelho d'água em homenagem ao trabalhador, e hoje, voltou a ser uma praça quase seca, depois da última intervenção de 2019, ou seja, possui pouca vegetação, como palmeiras e gramados.

A área de restrição de ocupação é "ocupada" pela Rodoviária, por espaços comerciais e a Feira da 44 que ocupa aproximadamente $1 / 3$ da área laranja e fica tomada por tendas azuis, cor padrão da cobertura dos camelôs.

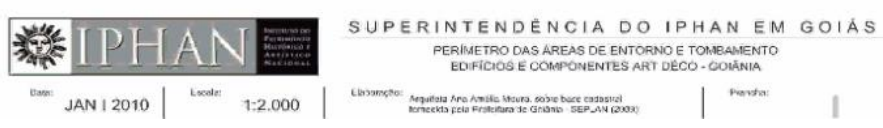

Figura 21. Situação e entorno da Estação Ferroviária de Goiânia, em Goiânia [GO]. Fonte: IPHAN / GO, 2010. 


\subsection{ESTAÇÃo FERROVIÁRIA DE BRASÍLIA}

A ideia mudancista de uma nova Capital Federal interiorizada, de alguma maneira passou pelas mentes que possibilitaram a mudança de algumas capitais estaduais, como Belo Horizonte e Goiânia. Outras cidades também cogitaram por seus representantes a possibilidade de se tornar a nova Capital Federal, mas sem efeito. Kallas, Silva e Guillen-Salas (2020) descrevem que a ideia “mudancista” iniciada com a Inconfidência Mineira, em 1789, somente concretizada em 1957, a partir do concurso para o Plano Piloto de Brasília, com a ideia vencedora de Lucio Costa.

Brasília "nasceu do gesto primário de quem assinala um lugar ou dele toma posse: dois eixos cruzando-se em ângulo reto, ou seja, próprio sinal da Cruz". - Foi assim que Costa (1957) descreve a concepção de Brasília e que depois por adaptação à topografia local arquearia o desenho.

Em um dos eixos (o monumental) tem a proposição da sede administrativa em uma ponta e em seu extremo oposto a inclusão da estação ferroviária proposta por Lucio Costa (Costa,1957). A região da ferroviária, que está acima do que Lucio Costa chamou de "área municipal", inclui a zona industrial de pequeno porte e uma área de abastecimento que é "arrematada pela estação ferroviária e articulada igualmente a um dos ramos da rodovia destinada aos caminhões”, nas palavras de Lucio Costa (1957). Atualmente, essa rodovia é intitulada de Estrada Parque Indústria e Abastecimento, ou EPIA, como é mais conhecida (Figura 22).

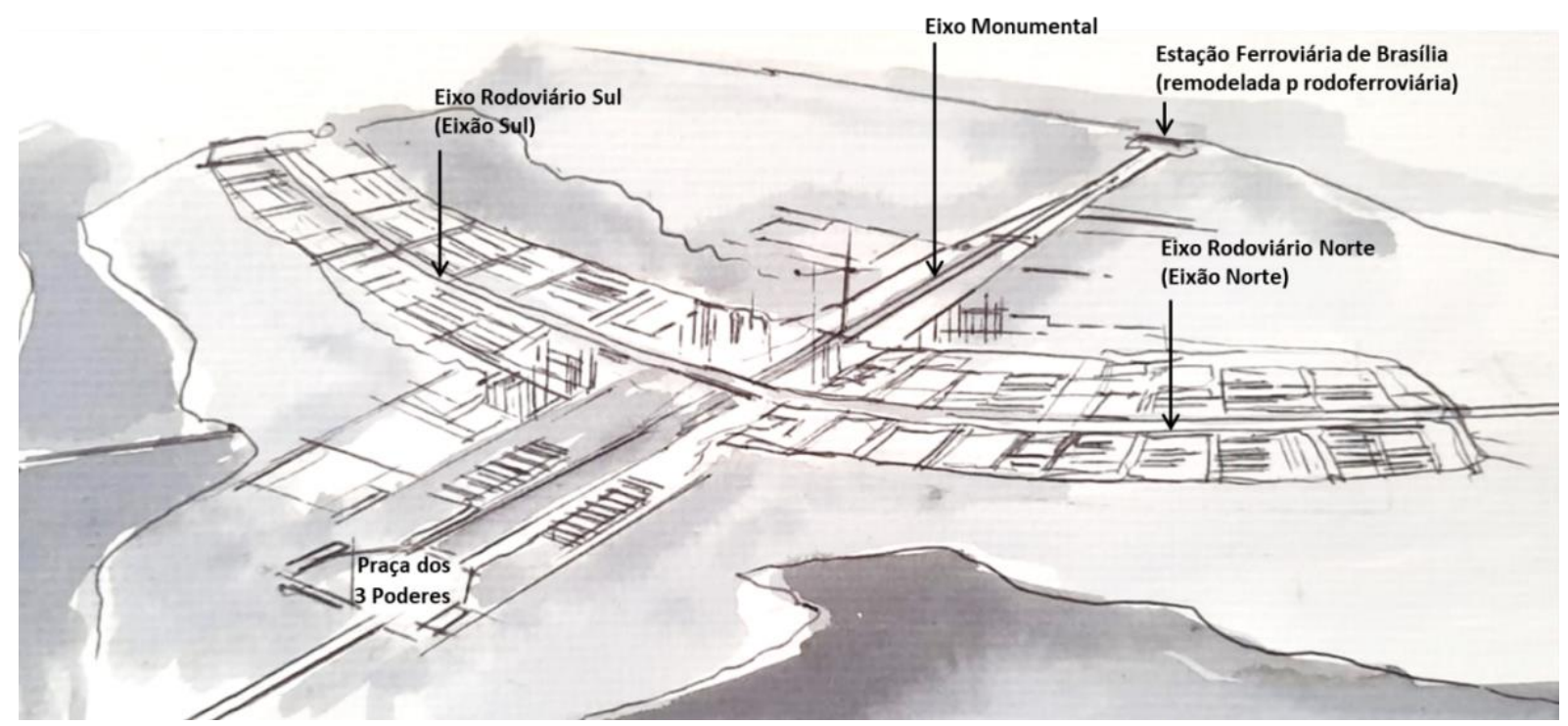

Figura 22. Esquema da concepção do Plano Piloto de Brasília de Lucio Costa. Desenho: Silva, 2021.

Apesar da posição estratégica da Estação Ferroviária de Brasília, não existia uma via férrea que chegasse até ela. No entanto, uma expansão ferroviária já fazia parte do Plano Nacional de Viação, que inclui o transporte ferroviário como meio de transporte e que este seria expandido rumo à oeste e apesar da proposição inicial da Estação Ferroviária de Brasília ter sido incluída no Plano Piloto de Brasília (em 1957), ela somente foi executada em 1970, pois até 1968, a linha férrea chegava somente até a estação Bernardo Sayão, localizada no Núcleo Bandeirante, e, que atualmente está abandonada. (Guedes \& Queiroz, 2007; Brasília, 1957b).

Para os estudos e construção ferroviária, Brasília (1957a, p.13) cita o decreto no 41.193, de 26/03/1957 que "atribui à Companhia Urbanizadora da Nova Capital do Brasil (Novacap) o estudo e a construção das linhas férreas de interesse do futuro Distrito Federal”. Dessa forma se estabeleceria a expansão férrea mais conveniente para o novo Distrito Federal e isso inclui os novos trechos que poderiam se ligar as estradas de ferro já existentes, como a Estrada de Ferro Goiás, segundo Brasília (1957b).

De acordo com Brasília (1957e) a nova Capital seria ligada aos dois centros comerciais de São Paulo e belo Horizonte por meio de linhas de trem. Nesse sentido, a ampliação da linha Pires do Rio-Brasília, teria um percurso de $230 \mathrm{~km}$, aproximadamente. Depois a ideia era prosseguir a linha a partir de Brasilia até a Colômbia, com um percurso de 650km, os registros dos documentos históricos da "Coleção de Revistas Brasília" cita muito pouco sobre esse trecho.

Nesse sentido, em 1958, com o intuito de averiguar a condições de ligação férrea entre Rio e Brasília, um trem chamado "Trem Brasília” saiu do Rio de Janeiro em direção à Brasília e o objetivo era "explorar o terreno 
ferroviário entre as duas capitais (a atual e a futura) a fim de que, até o próximo dia 30 o Grupo de Trabalho possa entregar o relatório sobre o levantamento estatístico do pessoal a ser transferido, seu alojamento e transporte (móveis) para a nova capital federal” (Brasilia, 1958b, p.18).

Ainda de acordo com a autora, essa viagem durou de 67 horas e levou a bordo 16 pessoas até Anápolis, sendo necessária a viagem por via rodoviária até Brasilia. De acordo com Brasilia (1958a), a rodovia de Anápolis a Brasília foi concluída com $130 \mathrm{~km}$ de asfaltamento para ligar a Nova Capital à Anápolis, onde se localizava a Estrada de Ferro de Goiás. Conformava o sistema rodoferroviário nacional.

Havia uma segurança de Israel Pinheiro, o então presidente da Novacap que as obras indispensáveis ao funcionamento da Nova Capital, como as ferroviárias estariam prontas até 1960, mas isso não aconteceu. No entanto, houve autorização no ano de 1958 para realizar concorrência administrativa a fim de construir 100 km da linha ferroviária partindo de Pires do Rio [GO] em direção a Surubi - atual Luziânia [GO] (Brasília, 1958c; 1958d).

Segundo Brasília (1957c, p.4), o trecho que ligaria Surubi- Brasília é um trecho de 82km e atenderia as duas grandes cidades, São Paulo e Brasília, e que deveria ter sido inaugurada em maio de 1958, além disso também seria concluída a "terraplanagem da esplanada de Brasília, com 300m de largura e $2 \mathrm{~km}$ de extensão que comportará a estação ferroviária para passageiros e cargas, armazéns, depósitos de locomotivas e vagões e

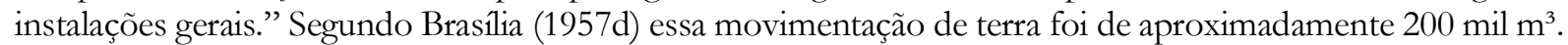
Esse seria o ponto de partida para extensão da comunicação via férrea para o Oeste rumo à Colômbia, fazendo jus à "Marcha para o Oeste" iniciada na década de 1930 e que continuaria com a retomada da ideia mudancista da Capital Federal que se concretizou com a construção de Brasília.

Mesmo com o terreno pronto (a Esplanada Ferroviária) para receber a estação ferroviária de Brasília, o local ficou vazio por bastante tempo depois da inauguração de Brasília. A estação ferroviária de Brasília seria até então o maior pátio ferroviário de acordo com Pátio (1970).

O projeto para a estação só teve início em 1970, por Oscar Niemeyer, sendo registrado em seu site como 1973. Além disso, a estação ferroviária passou por algumas fases sem apresentar um auge específico. Diante dos documentos existentes, pode-se definir que a Estação Ferroviária de Brasília passou por 5 fases, que são: uma pré-fase à construção da estação, ou da expansão da linha férrea que possibilitou anos depois a construção da Estação Ferroviária de Brasília; mais as 4 fases seguintes: $1^{\mathrm{a}}$ fase - O projeto e sua construção (1973-1976); $2^{\mathrm{a}}$ fase - Inauguração e abandono (1974-1980); $3^{\mathrm{a}}$ fase - Adequação e insuficiência (1981-2007); e $4^{\mathrm{a}}$ fase Substituição e $2^{\circ}$ abandono (pós-2007).

\subsubsection{PRÉ-FASE À ESTAÇÃO - LINHA FÉRREA E PREPARO DO PÁTIO FÉRREO (1957-1972)}

De forma resumida, o interesse em construir uma linha férrea e os estudos para ampliação da linha férrea do Rio de janeiro até Brasília ocorreu entre 1956 e 1958, consolidada com a viagem do Trem Brasilia que durou 67h.

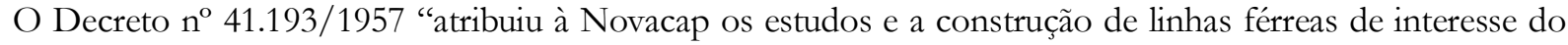
futuro do Distrito Federal”. A liberação para construção da linha férrea teve início em 1958 e sua conclusão ocorreu com a consolidação da terraplanagem do pátio férreo no Plano Piloto, que de acordo com Pátio (1970) ocorreria em 1972 e que comportaria:

Exatamente 1 milhão e 6 mil metros quadrados abrigarão os armazéns particulares do Setor de Abastecimento e Armazenagem [SAAN?], restando mais $558.700 \mathrm{~m}^{2}$ para o Centro Integrado de Abastecimento de Brasília. (Pátio, 1970).

É importante salientar, que como a Esplanada ferroviária e a estação ferroviária, hoje antiga Rodoferroviária não são tombadas, esses espaços ficam suscetíveis as intervenções da cidade sem as devidas proteções de tombamento. Nesse sentido, de acordo com Cavalcanti (2013) houve discussões sobre o Plano de Preservação do Conjunto Urbanístico de Brasília (PPCUB) em 2013, que afetaria a Esplanada Ferroviária com uma "proposta de liberar a Esplanada Ferroviária para a criação de um novo núcleo urbano foi um dos quatro itens que provocaram as maiores reações, e que acabaram retirados do PPCUB pelo Governo do DF" e como comprovado em Governo (2017).

De acordo com o autor, eram muitas interferências que incluíam o Parque Ferroviário de Brasília, ou o Setor ferroviário ou a Rodoferroviária e seu entorno. Dessa forma, a falta do tombamento gera problemas que 
podem afetar diretamente esses espaços e que poderiam ser de certa maneira minimizados, caso já tivessem sido tombados.

\subsection{2. (1970 OU 1973?) 1ª FASE: O PROJETO ARQUITETÔNICO DA ESTAÇÃO FERROVIÁRIA}

Embora toda a terraplanagem tivesse pronta, o edifício ferroviário para passageiros, projeto de Oscar Niemeyer (ver Figuras 23, 24, 25 e 26) foi projetado em 1970, mas a informação do projeto por Niemeyer (1973), é o ano de 1973 e foi assim concebido:

A solução que propomos localiza no pavimento térreo o grande hall, as bilheterias, os controles, o comércio, bares, etc, $e$ os órgãos ligados ao público; no primeiro pavimento, os serviços administrativos, o restaurante e, completamente independente (com acesso externo privativo) o posto médico. No subsolo, dois halls, um para os que partem e outro para os que chegam, diretamente ligados ao hall principal, às plataformas e ao estacionamento de táxis.

Essa solução evita as passarelas sobre as linhas substituindo-as pelos [...] halls (com comércio ... etc) solução que reduz a altura das escadas de $6 \mathrm{mts}$ para $4 \mathrm{mts}$. permitindo que os passageiros que chegam atinjam facilmente os locais de estacionamento de táxis (a construção será simples, pré-fabricada: lajes de piso e cobertura; vigas e lajes de cobertura das plataformas) (Niemeyer, s.d.).

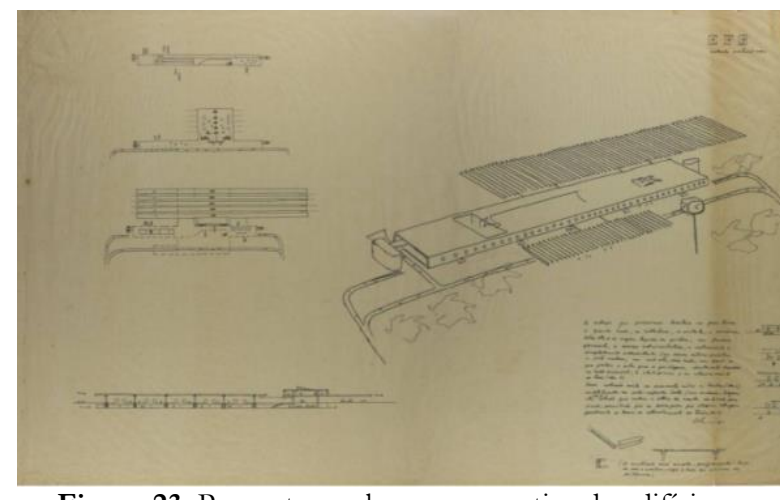

Figura 23. Proposta geral com perspectiva do edifício. Fonte: Niemyer (1973).

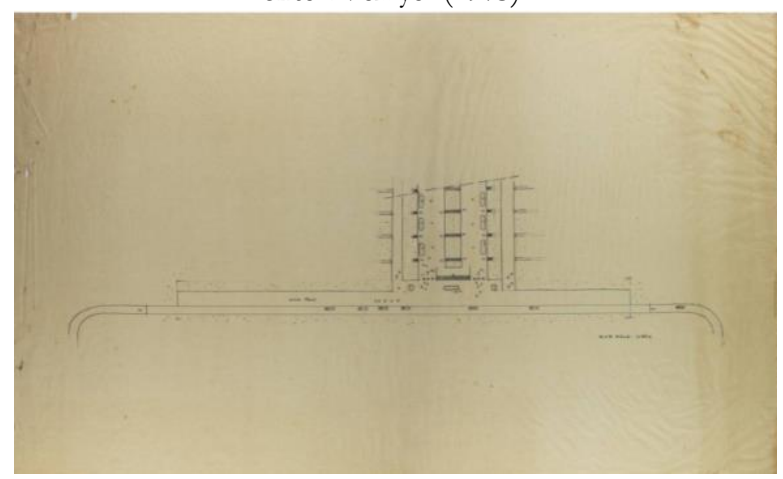

Figura 25. Proposta subsolo do edifício. Fonte: Niemyer (1973).

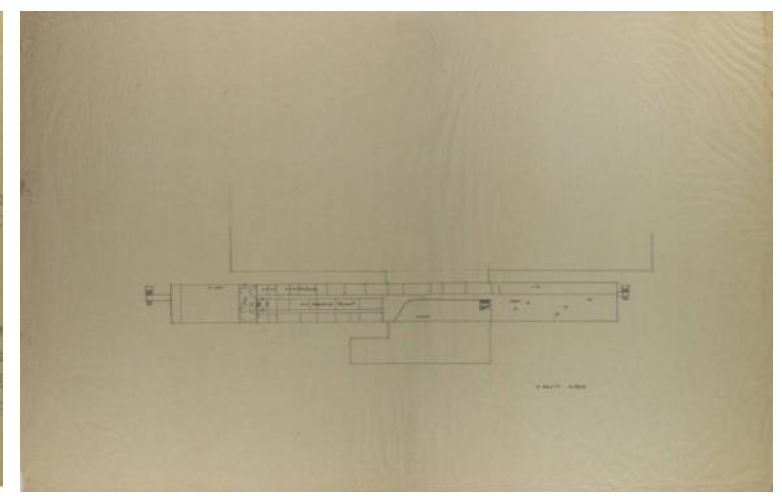

Figura 24. Proposta para o $1^{\circ}$ pavimento do edifício. Fonte: Niemyer (1973).

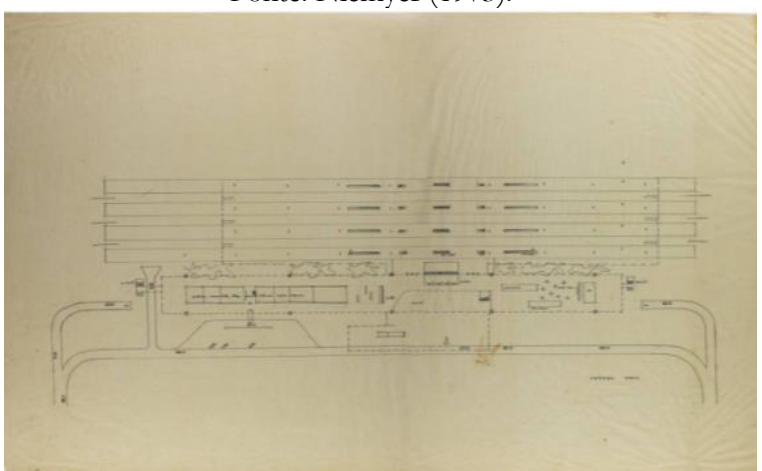

Figura 26. Proposta para o Térreo do edifício. Fonte: Niemyer (1973).

A proposta modernista de Niemeyer é uma construção em concreto aparente, possuindo vigas vienrendel apoiados em cinco pilares robustos de cada lado, uma longa estrutura horizontal com 45 janelas dos dois lados emulando um vagão de trem. Em cada ponta do edifício um bloco de circulação vertical. Planta livre, conforme os preceitos da Carta de Atenas. Acesso nas laterais do edifício para táxis e que permite o embarque e desembarque nos 2 halls do subsolo.

O projeto proposto para a estação contemplava inicialmente a construção de 5 plataformas segundo Niemeyer (1973) esquema apresentado na Proposta geral do projeto por Niemeyer com o térreo e o corte (Figura 23), enquanto que na Figura 26 de forma ampliada o projeto é apresentado com apenas 4 plataformas. No entanto, foram executadas apenas 2 plataformas, sendo que uma delas foi pavimentada para o uso rodoviário interestadual, em 1976.

$\mathrm{O}$ acesso às plataformas é realizado pelo subsolo por meio dos halls que possuem escadas que acessam o térreo local de embarque e desembarque aos trens. É possível visualizar na proposta geral, por meio dos cortes, e das plantas esquemáticas (Figuras 23 e 25). 
No primeiro pavimento, menos movimentando, conforme descrito por Niemeyer, estão os serviços administrativos, restaurante e posto médico, onde também há um jardim de inverno (Figura 24).

Essas considerações foram apontadas observando as Peças gráficas que compõem o projeto da estação ferroviária de Brasília.

No edifício há ainda dois trabalhos de Athos Bulcão, na parte frontal, uma cerâmica com desenhos de telefones. E na parte das escadarias que acessam o piso superior, no forro, peças em alumínio propiciam um efeito visual diferenciado e ao mesmo tempo, auxiliam na dispersão da iluminação artificial, como também podem auxiliar na redução do ruído da estação.

\subsection{3. (1970-1980) 2ª FASE - DE ESTAÇÃO FERROVIÁRIA EM DESUSO A RODOFERROVIÁRIA}

Pátio (1970) comenta que o convênio firmado em 27 de julho de 1970 com a Novacap haveria destinado um montante de "Cr\$30 milhões para o projeto completo da estação definitiva, encarregando-se da construção e dos serviços de urbanização do pátio e suas imediações, acessos rodoviários e extensão das redes de eletricidade, águas, esgotos e serviços complementares."

Apesar do tempo investido até a construção da estação definitiva, a Estação Ferroviária de Brasília, Pátio (1970) informa que a "estação ferroviária provisória" teria uma movimentação de passageiros na ordem de 150 mil usuários. Além disso, o autor, afirma também que a os produtos transportados como carga predominante são: "cimento, madeira, gasolina e óleo".

As obras da estação definitiva se iniciariam em 1971 e estariam concluídas em 1972 (Pátio, 1970; Brasília, 1970). No entanto, um artigo sobre a nova estação de Brasília, possivelmente publicado em 1972 na Revista Refesa (Centro-Oeste, 1972?) indica que a obra seria concluída em 1974 como fora anunciada pelo então "Ministro Mário Andreazza, dos Transportes, quando lhe foi apresentada a maquete do projeto". Porém, para esta pesquisa não foi encontrada a data de conclusão de sua obra, e a Estação ficou sem uso até 1976, quando passou a se chamar Rodoferroviária.

Registros identificaram que em 1976, devido ao aumento da frota de ônibus distritais e interestaduais na Rodoviária do Plano Piloto, o Governo do Distrito Federal alugou a Estação Ferroviária para transferir a frota de ônibus interestaduais, em troca de urbanização do entorno da Estação Ferroviária, passando a se chamar de Rodoferroviária. Na adaptação, uma das plataformas de trem foi convertida em plataforma rodoviária ao ser pavimentada. Enquanto isso, a outra plataforma continuou a ser utilizada para a ferroviária. Contudo, somente em 1981, a parte ferroviária foi (re)inaugurada com o Trem Bandeirante para passageiros.

\subsection{4. (1981-1991) 3ª FASE - RODOFERROVIÁRIA: O RETORNO DO TREM DE PASSAGEIROS E O SEU DECLÍNIO}

A inauguração da Estação Ferroviária de Brasília (a definitiva), em 1981, não teve o entusiasmo e a festividade, como quanto à chegada do trem à Estação Bernado Sayão, em 1968, localizada no Núcleo Bandeirante, no Distrito Federal.

De acordo com Ferrovias (1968), Labert e Cavalcanti (2017), “em 21 de abril de 1968, na comemoração de oito anos da Capital, o primeiro trem de passageiros chegou à estação Bernardo Sayão ao som da música 'A banda', de Chico Buarque, em uma grande festa", mas como descreveu os autores, isso foi na Estação Bernardo Sayão; já na Estação definitiva, para esta pesquisa não se encontrou informações a respeito da inauguração, não sendo utilizada até sua reinauguração, em 1981. Ao que tudo indica que de 1974 a 1981 , a Estação Ferroviária de Brasília ficou desativada.

Em 1981, de acordo com trem Bandeirante (1981) o então presidente da República Fiqueiredo retoma obras do antigo governo (Geisel) e entre elas está a inauguração da Estação Ferroviária de Brasília, após uma viagem saindo da Estação da Luz em São Paulo e chegando a Brasília 25 horas depois da partida "e a chegada marca a inauguração do Setor Ferroviário de Passageiros do terminal brasiliense. Em 8 de maio, as viagens tornamse semanais" (Anos 1980, 2018).

Os registros apresentados por Trem Bandeirante (1981) é que a parte ferroviária após sua inauguração tem um auge no uso de seus serviços em 1986, com o aumento para duas viagens semanais saindo de Brasília, a partir de 1990, com o Plano Collor I em ação, que foi um confisco das reservas da população brasileira, fez com que 
a população reduzisse seus gastos e o trem deixou de ser usado; em 1991, o declínio continua - alcançando o ano de 1992, o que fez o Trem Bandeirante se aposentar.

Com a alta demanda da Plataforma da Rodoviária no "centro" de Brasília, o transporte de passageiros interestadual foi transferido para a estação ferroviária, que foi repaginada e adaptada para receber o transporte rodoviário, passado a ser Terminal Rodoferroviário. O inquilino “[...] em troca, fez a urbanização, asfalto, iluminação pública, gramado etc. Quando o governo Figueiredo reinaugurou o Trem Bandeirante, em 1981, ela já estava funcionando normalmente". A estação atendeu trens de passageiros até 1991, mas continuou a atender trens de cargas. Enquanto isso, a parte rodoviária atendia o transporte interestadual de passageiros até a construção de uma nova Rodoviária Interestadual, que se localizaria próxima a uma linha de metrô (Flávio Cavalcânti, 2006).

\subsection{5. (1992-2021) 4ª FASE - DESATIVAÇÃO DA RODOFERROVIÁRIA E USO POR ÓRGÃOS PÚBLICOS DO GDF}

Depois da desativação do Trem Bandeirante, em 1991, a Rodoferroviária que manteve o nome, continuou como Rodoviária para passageiros e como ferrovia para o transporte de carga. Até que em 2005, o então Governador Roriz anuncia a construção de uma nova rodoviária e que a mesma seria inaugurada em 2006. O novo lugar estaria em uma situação estratégica de ligação com o metrô, acesso a um shopping (Centro-Oeste, 2005).

Em 2007, a RFFSA é finalizada e liquidada e passa todos os bens à União, por meio da Lei $\mathrm{N}^{\circ} 11.483$, 31/05/2007 que dispõe sobre a revitalização do setor ferroviário e assim "Caberá ao Instituto do Patrimônio Histórico e Artístico Nacional - IPHAN receber e administrar os bens móveis e imóveis de valor artístico, histórico e cultural, oriundos da extinta RFFSA, bem como zelar pela sua guarda e manutenção.” E caso o bem seja operacionável, que o IPHAN garanta o compartilhamento para o uso ferroviário.

A Lei está em vigor desde 2007, e 14 anos depois a situação aparenta abandono. Pois conforme determina a lei, "a preservação e

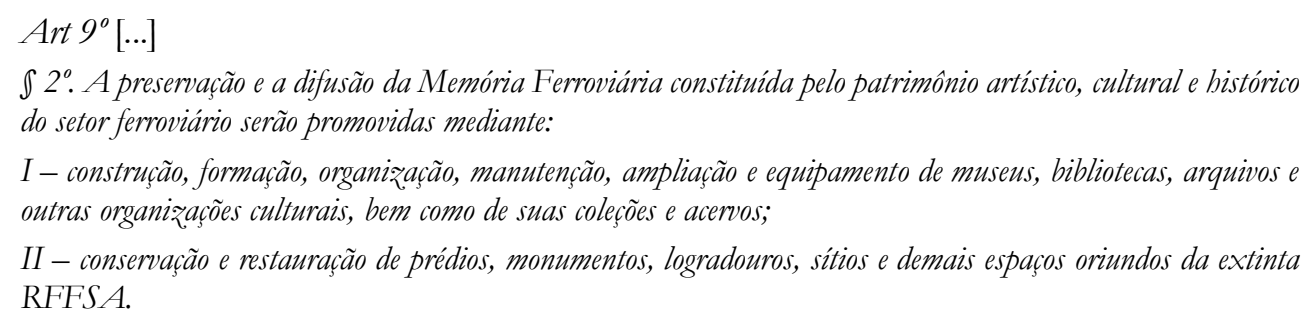

É importante ressaltar que nem a estação ferroviária provisória, nem a estação ferroviária definitiva, Bernardo sayão e a Rodoferroviária ainda não foram tombadas, a primeira totalmente abandonada e ocupada por famílias que fecharam a estação como uma residência. E a segunda, a antiga Rodoferroviária, é ocupada por alguns órgãos públicos vinculados ao Governo do Distrito Federal.

Lá se vão 15 anos desde a sua desativação enquanto Rodoviária, pois como ferroviária de passageiros foi desativada há mais tempo, 30 anos. No entanto, como ferroviária de transporte de carga, de acordo com o Anuário RF (2015, p.27), é operada pela FCA e Lemos, e transporta os seguintes produtos: areia, bauxita, gasolina, óleo diesel e coque de petróleo.

De acordo com Cidades (2010) houve uma ideia de transformar a antiga Rodoferroviária no primeiro Museu de Ciência e Tecnologia da Capital do estado de Goiás, mas com um orçamento de R \$55 milhões à época para investir na requalificação do espaço, a ideia não seguiu adiante, e como já descrito, o espaço continua ocupado por órgãos públicos.

\section{Os ediíícios da antig̉a estação ferroviária de Goiânia e da antigaa rodoferroviária de Brasília: representaç̃o por Sketches, conhecendo a cidade e a educação patrimonial}

Conhecer um novo lugar ou revisitá-lo é um momento de grande aprendizado, não só para um estudante de arquitetura e urbanismo, um arquiteto e urbanista, mas para qualquer pessoa que queira conhecer um pouco mais o local em que vive ou que transita. E quando se associa esse conhecimento com uma forma de registro do lugar, a experiência se torna particularmente mais intensa na memória das pessoas. 
Os registros podem ser por meio da fotografia, do desenho ou da pintura. Hoje, a mais fácil é a fotografia, que com um celular, o registro é instantâneo e também prático. No entanto, um registro mais antigo tem se popularizado, o desenho. Kallas, Guillen-Salas e Silva (2020) têm apresentado historicamente como o desenho e a pintura desde os primórdios têm sido usados como registros do cotidiano, como as pinturas rupestres, os desenhos dos paisagistas do passado que viajavam o mundo retratando o cotidiano por onde passavam, chegando aos dias de hoje, pelos grupos de desenho ao ar livre que tem se difundido pelo mundo.

Essa prática que hoje é bastante difundida, desejada e bem aceita foi incentivada por um movimento de rua, o movimento internacional Urban Sketchers, que tem resgatado essa forma antiga de registro e que cativa cada vez mais adeptos. É importante, salientar que para desenhar não é necessário fazer parte do grupo, pode ser uma prática solitária, de pequenos ou grandes grupos, como o que ocorre com o movimento Urban Sketchers ou Croquis Urbanos, ou Goiânia em Traços, ou de seus derivados, onde vários outros grupos se formaram e continuam se formando em busca de desenhar os espaços, a cidade, a arquitetura, as pessoas, como forma de prazer, arte, cultura e educação.

Aliado a esse processo, o desenho urbano trouxe uma prática também já conhecida de educação patrimonial e ensino da arquitetura, como citado por Kallas, Guillen-Salas e Silva (2020), Del Rio (2016), Choay (1999), sobre a prática de desenhar juntamente com o flâneur, a deriva, o caminhar que descobre os lugares da cidade em seus detalhes.

O movimento Urban sketchers e outros tem em seus diversos membros uma variedade de técnicas e representações, por vezes uns seguem uma escola clássica, outros nem tanto, mas o que importa neste processo é o desenho, o prazer que a pintura proporciona, o lugar a ser conhecido, o registro individual e ao analisar os desenhos e pinturas divulgados em redes sociais do grupo (acesso aberto), pode-se observar que a cidade contemporânea é sempre palco de suas representações, mesmo que o objeto histórico representado no papel tenha centenas de anos ou pertença a uma história mais recente, há sempre elementos que caracterizam a contemporaneidade.

Assim como os grandes mestres da pintura a seu tempo representaram a modernidade que havia chegado com o ferro e o aço, por meio das Marias fumaças ou suas locomotivas, vagões e os trilhos percorridos, apresentando uma paisagem urbana e a vida moderna, com uma paleta de cores representando o momento registrado, como Monet, ou a representação dos vagões, do contraste entre campo versus cidade, uma paleta de cores mais intensa como a de Van Gogh.

Já os Urban Sketchers representam claramente a contemporaneidade. A maioria dos Urban Sketchers representa as cores do momento registrado, elementos da cidade contemporânea, como a edificação, fios, postes, lâmpadas e suas luminárias, o piso, o concreto, o asfalto, uma mudança aqui e ali no traço, por vezes se inclui os calungas, ou seja, a figura humana estilizada, mas com alguma proporção. No caso das cenas urbanas brasileiras, representa-se também a intensidade do azul do céu, a vegetação abundantemente verde, a diversidade das cores das edificações, tentando registrar o momento como uma fotografia colorida, mas por meio do desenho, captando o máximo de detalhes possíveis de serem desenhados, levando em consideração o tamanho do suporte de registro, normalmente um sketchebook no tamanho A5 ou A4, ou seja, um caderno de desenhos, mas de todo modo, existem as exceções a esse tipo de representação.

A materialidade da contemporaneidade é o ferro, o aço, o plástico, o adobe, o tijolo, é um misto disso e muito mais, o registro pelos Urban Sketchers segue o que se vê, aliás, a primeira regra do manifesto do Movimento é: "nós desenhamos no local, dentro ou fora, capturando o que vemos por observação direta" (Urban Sketchers, 2021). Dessa forma, a técnica é livre, mas a representação considera o que se vê pela observação, o que pode resultar em uma "limpeza" da imagem. O manifesto ainda direciona aos membros que o desenho ou pintura possa ser uma narrativa do espaço vivido, em um determinado tempo e lugar, registrando um pouco da história da cidade por meio de diversos estilos individuais.

O desenho de rua possibilita conhecer a cidade e descobrir detalhes da história da cidade de várias formas: por observação; e ao ouvir parte da história do lugar por um transeunte que vivenciou aquele espaço; ou ainda, por um guia turístico que estudou sobre o lugar. Se o local for um Museu, a história contada preenche o desenho e a memória de quem desenha. Parafraseando Del Rio (2016) ao caminhar você conhece mais a cidade, descobre e redescobre e quando aliado ao desenho você aproveita mais o lugar propiciando registrá-lo e entender o lugar. 
O desenho ensina, educa, memoriza, cria uma cultura de valor, de resgate do patrimônio, cria laços de pertencimento e identidade com o lugar. A documentação aparente por meio dos sketches é tema tratado por Kallas, Guillen-Salas e Silva (2020), Kallas, Silva e Guillen-Salas (2020), Viollet-le-Duc (2006) e utilizado como estudos por Boito (2008).

Nesse sentido, os grupos de desenho que se espalharam pelo Brasil e mundo afora, entre outras coisas, acabam por "contribuir para a apropriação da cidade e a criação da noção de pertencimento" de acordo com Kallas, Silva e Guillen-Salas (2020).

E com a intenção dessa contribuição para se apropriar da cidade, criar um elo maior com a cidade e ao mesmo tempo, criar uma forma de educação patrimonial, proposta que o Goiânia em traços seguiu em 2017, um projeto de extensão sobre a valorização e resgate patrimonial, como o que ocorreu em um de seus encontros na Estação Ferroviária de Goiânia que havia acabado de ser reinaugurada após sua revitalização em maio de 2019, onde foi possível conhecer um pouco mais da história da cidade, por meio da exposição do Frei Confaloni e seus painéis na área da antiga bilheteria da estação.

Na antiga Estação Ferroviária de Goiânia, apesar de sua renovação ter diminuído um pouco do visual de abandono de antes, espera-se que o local possa ter momentos de maior movimentação com as novas atividades, como o uso para serviços da Prefeitura, exposições e o Chorinho bem como, mais políticas públicas culturais que assegurem a manutenção e uso do local de forma adequada, uma vez que é um espaço público de excelência na cidade, por suas áreas para exposição, pela própria Estação e sua Maria Fumaça do lado de fora.

De outro lado, e apesar de sua revitalização ter ocorrido em 2019, sinais de que sua pintura precisa de retoques já apareceram. Além disso, a estação também é ocupada pelo Atende Fácil da Prefeitura Municipal de Goiânia, que é um dos pontos de atendimento/solicitação do público à prefeitura. Na edificação também é possível visualizar os murais e um acervo do Frei Confaloni, que de acordo com Frei (2021) é "Pintor, muralista, desenhista, professor e Frei e [...] um dos pioneiros da arte moderna em Goiás”.

Na parte externa, além da Maria Fumaça (exposta permanentemente), e onde está inserida a antiga Estação, é a praça dos Trabalhadores modificada algumas vezes, já possuiu um monumento aos trabalhadores, mas foi demolido e hoje a praça é livre de outras edificações, inclui um paisagismo simplificado com presença de palmeiras e seu entorno é constantemente ameaçado pela ocupação da Feira da 44, uma feira que ocorre aos finais de semana e parece crescer a cada dia.

A estação Ferroviária de Goiânia e sua Maria Fumaça são um Museu a céu aberto, uma parte da história de Goiânia valorizada e resgatada por meio dos sketches por desenhistas que percorrem a cidade. A seguir algumas representações da antiga Estação Ferroviária de Goiânia, apresentando algumas características e elementos mais marcantes da edificação e da paisagem como nas Figuras 27, 28 e 29 que apresentam as linhas marcante do Art Déco, o relógio característico da edificação, a pavimentação e parte do gramado no entorno imediato a edificação, e apesar das palmeiras e árvores presentes na Praça, o aspecto é de aridez. Já na Figura 30, a imagem foi retratada desde a Avenida Goiás em 2021, onde a estação aparece atrás de postes e da fiação elétrica que poluem a paisagem, mesmo assim a forma marcante da Estação se sobressai.

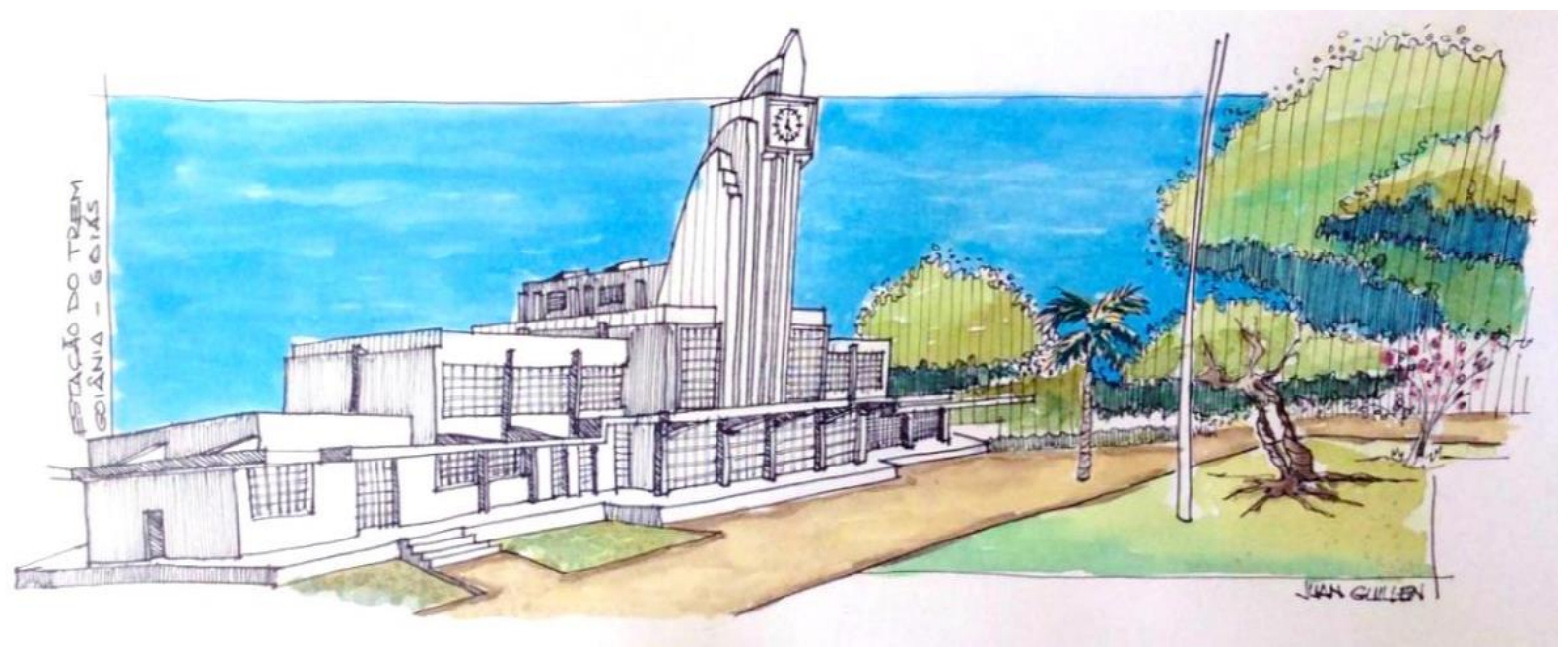

Figura 27. Parte frontal da Estação de Goiânia. Desenho: Juan Guillen, 2019. 


\section{Labor \& Engenho}

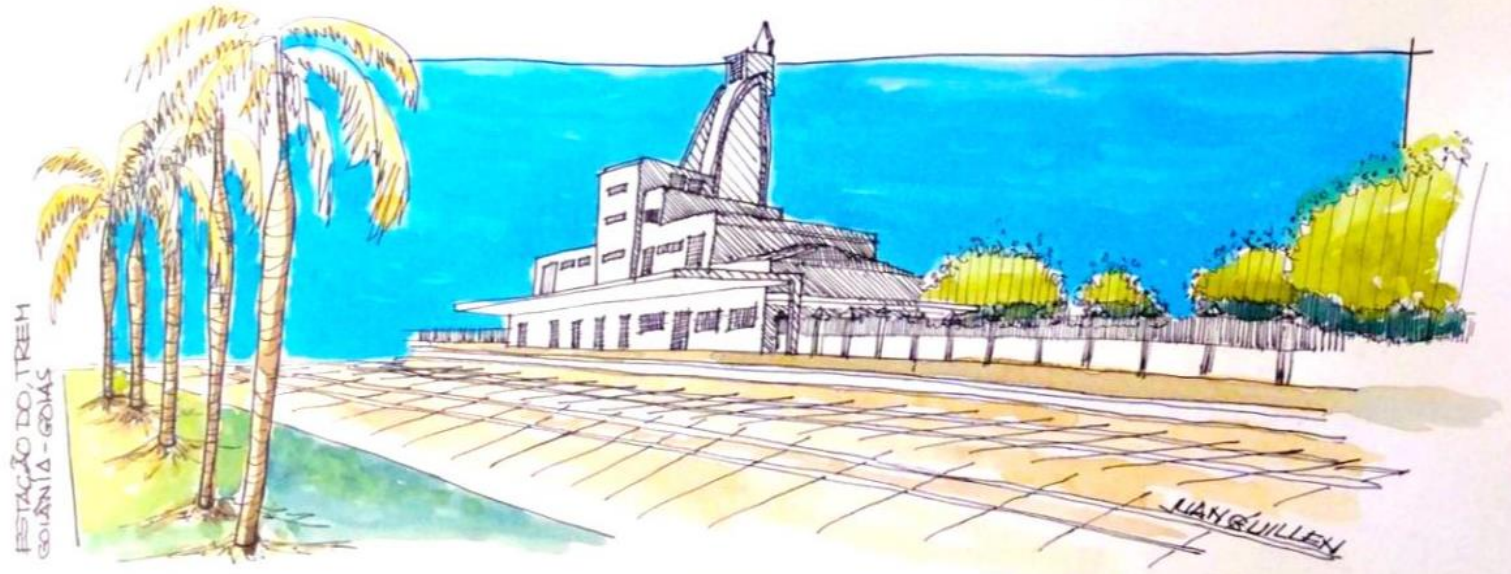

Figura 28. Parte Posterior da Estação de Goiânia. Desenho: Juan Guillen, 2019.

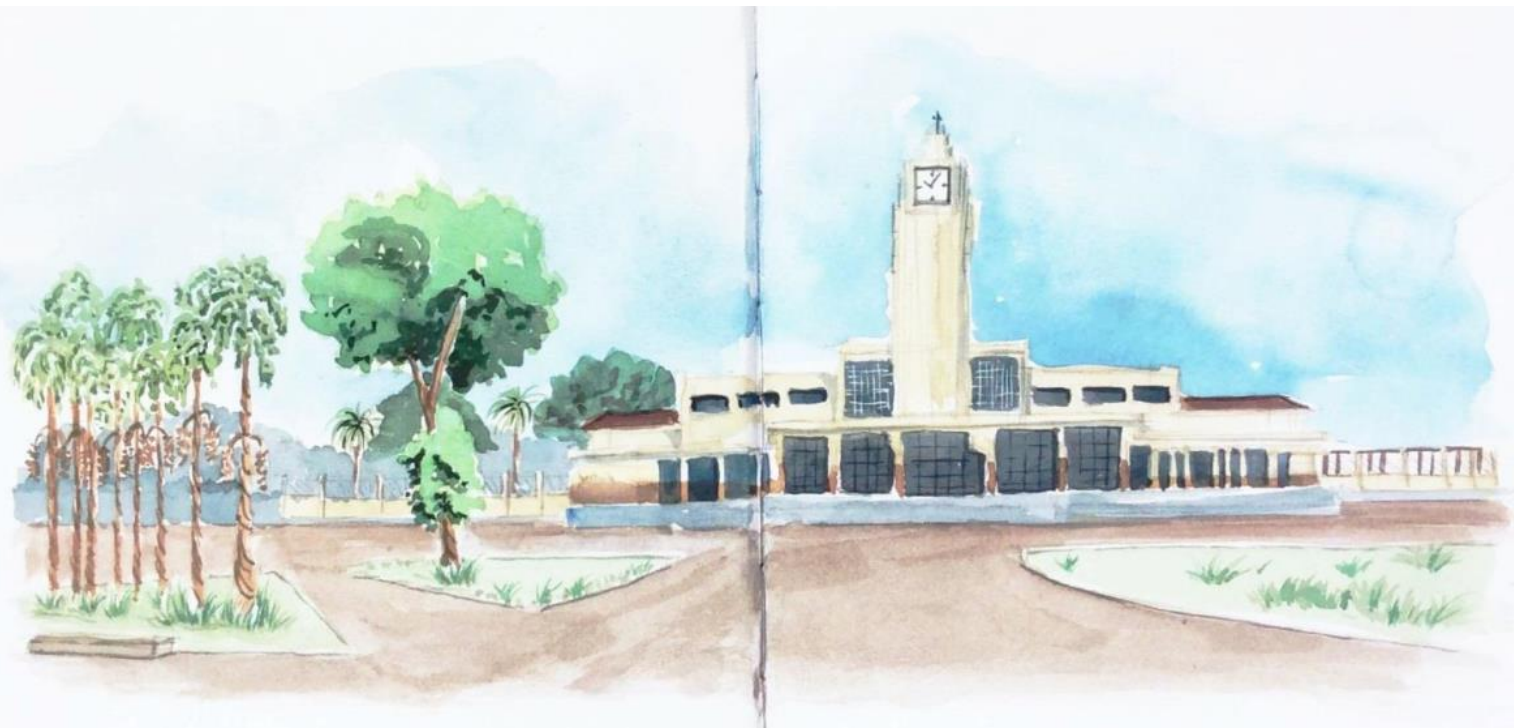

Figura 29. Parte Frontal da Estação de Goiânia com parte da Praça dos Trabalhadores, vista desde a Praça dos trabalhadores. Desenho: Luana Kallas, 2019.

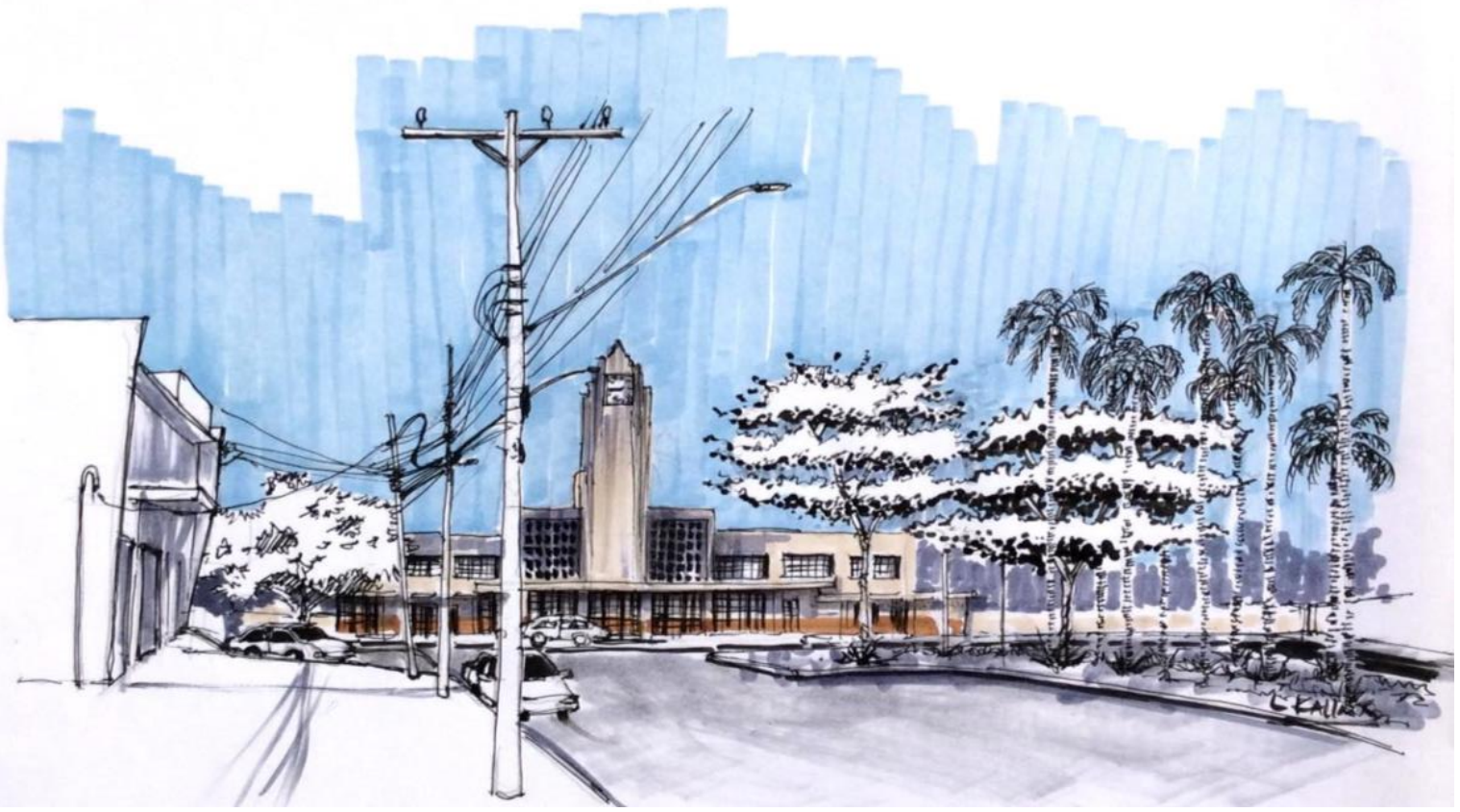

Figura 30. Vista da Estação Ferroviária de Goiânia desde a Av. Goiás (atual), marcada pela presença contemporânea dos postes de iluminacão e a fiacão elétrica. Desenho: Luana Kallas. 2021. 
Em Brasília, onde o grupo Urban Sketchers de Brasília [DF] já realizou um de seus mais de 60 encontros, fica a antiga estação Ferroviária de Brasilia ou como atualmente é conhecida, antiga Rodoferroviária. Um resgate das memórias de quem vivenciou o lugar em algum momento de sua história por meio de sketches, são aqui representados pelos desenhos dos autores que se mesclam com outras idas ao local com o objetivo de captar um pouco mais do local por meio de sketches.

Na localidade ainda é possível visualizar a parte externa do edifício, pois tudo foi tomado por órgãos públicos do Distrito Federal, com acesso restrito. Dessa forma, da parte externa frontal, ficam à vista as cerâmicas brancas de Athos Bulcão com desenhos em formato de telefone na cor preta, assim como ficam à vista as janelas do edifício que se parecem janelas de vagões de trem no volume horizontal em concreto sobre cinco pilares robustos de cada lado. Na parte externa posterior, à vista estão as divisórias em concreto que separam duas plataformas: a primeira, asfaltada para o uso rodoviário e a segunda, mantida como original e ainda em uso apenas para trens de carga. Em outro dia de visita ao local, na parte posterior estavam à vista os vagões de bauxita, que de acordo com os funcionários do local, iriam para Santos. A parte da plataforma asfaltada estava fechada com grades, assim como os acessos ao subsolo da edificação em concreto.

Apesar, da edificação da antiga Rodoferroviária ter seu uso desativado para passageiros, o edifício hoje acomoda alguns órgãos públicos ligados ao Governo do Distrito Federal (GDF). É importante salientar, que o local é pouco frequentado, mas que já houve interesse em transformá-lo em Museu.

Salvaguardar o local como espaço da história de Brasília é muito importante, por fazer parte da concepção do conjunto urbano de Brasília, está na proposta original de Lucio Costa para o Plano Piloto de Brasília, mesmo que o local tenha sido executado mais de 10 anos depois da inauguração de Brasília deve ser preservado, deve ser tombado. O local já passou por alterações ao se tornar Rodoferroviária, e depois reabilitado uma segunda vez para o uso de órgão públicos do GDF.

A antiga Rodoferroviária ainda possui grafite em uma de suas laterais descaracterizando a construção em concreto. O stand adaptado, da época de uso da parte rodoviária, não existe mais. O local não é visto desde o Eixo Monumental, pois há uma alça que passa por cima da EPIA para chegar à edificação. Nos finais de semana, famílias e grupos usam a parte do estacionamento para prática esportiva, como bicicleta, skate, etc. $\mathrm{O}$ local tem boa arborização e sombra na parte frontal do edifício, mas a edificação não tem acesso público.

Os sketches das Figuras 31, 32, 33, 34, 35 e 36 representam a materialidade característica do edifício, concreto aparente e suas janelas semelhantes a de vagões de trem. A arborização, o estacionamento e o gramado, que são frutos da urbanização do entorno do edifício quando da primeira reabilitação para uso Rodoviário, sendo novamente modificado somente quando o Shopping Popular de Brasília ao lado da Rodoferroviária surgiu, em 2008, para retirar os ambulantes do Setor Comercial Sul e da Rodoviária do Plano Piloto.

Nos sketches das Figuras 31 e 35 as cerâmicas do Athos Bulcão são visíveis de forma estilizada. Nos sketches das Figuras 32, 33 e 34 as escadas laterais em concreto são visíveis como um corpo destacado da edificação principal, além dos pilares robustos e um dos acessos ao subsolo. E na Figura 36 vagões aparentemente abandonados no pátio férreo.

Das imagens registradas, tem-se a materialidade preponderante na representação, o concreto no caso da edificação e o aço dos vagões, com técnicas de tinta, aquarela e marcadores. O edifício com a repetição de janelas, o trabalho do concreto aparente e as cerâmicas do Athos Bulcão marcam a edificação. A grande área no entorno e o acesso à parte posterior da edificação que torna visível o pátio férreo ainda em uso para o transporte de cargas.

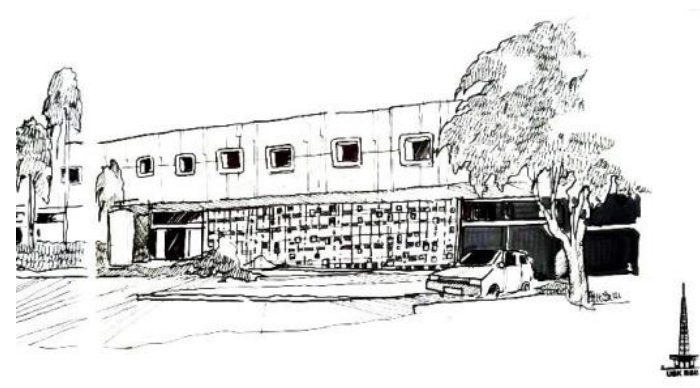

Figura 31. Vista da antiga Rodoferroviária, painel em cerâmica do Athos Bulcão e parte das janelas frontais.

Desenho: Eliel Américo, 2016.

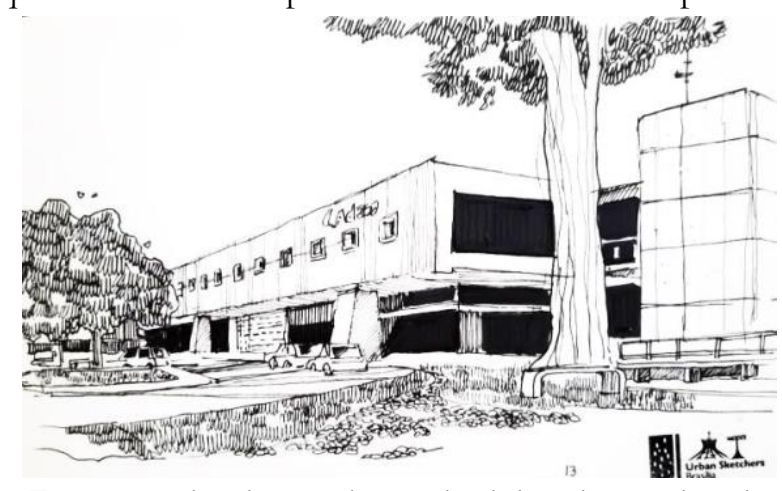

Figura 32. Vista de parte das escadas da lateral Norte da antiga Rodoferroviária e parte das janelas frontais.

Desenho: Eliel Américo, 2016. 


\section{Labor \& Engenho}
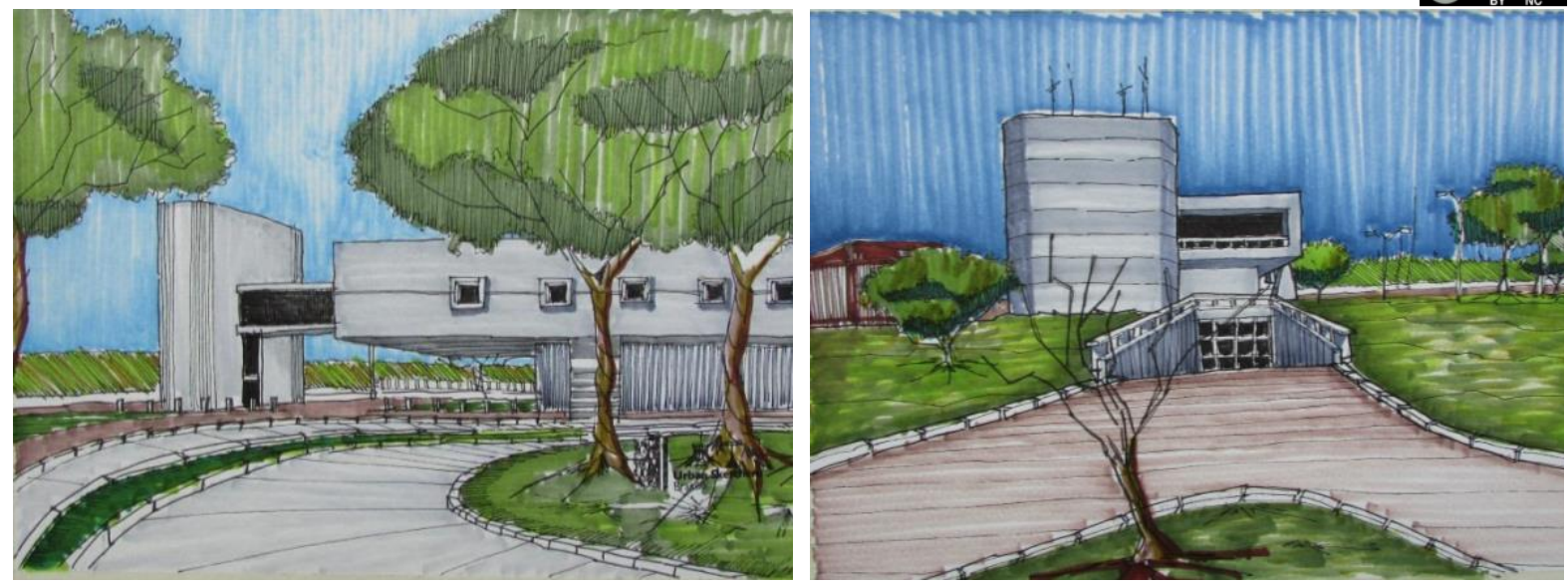

Figura 33. Vista das escadas da lateral Sul da antiga Rodoferroviária e parte das janelas frontais. Desenho: Juan Guillen, 2016.

Figura 34. Vista lateral Sul da antiga Rodoferroviária e vista do acesso ao subsolo. Desenho: Juan Guillen, 2016.
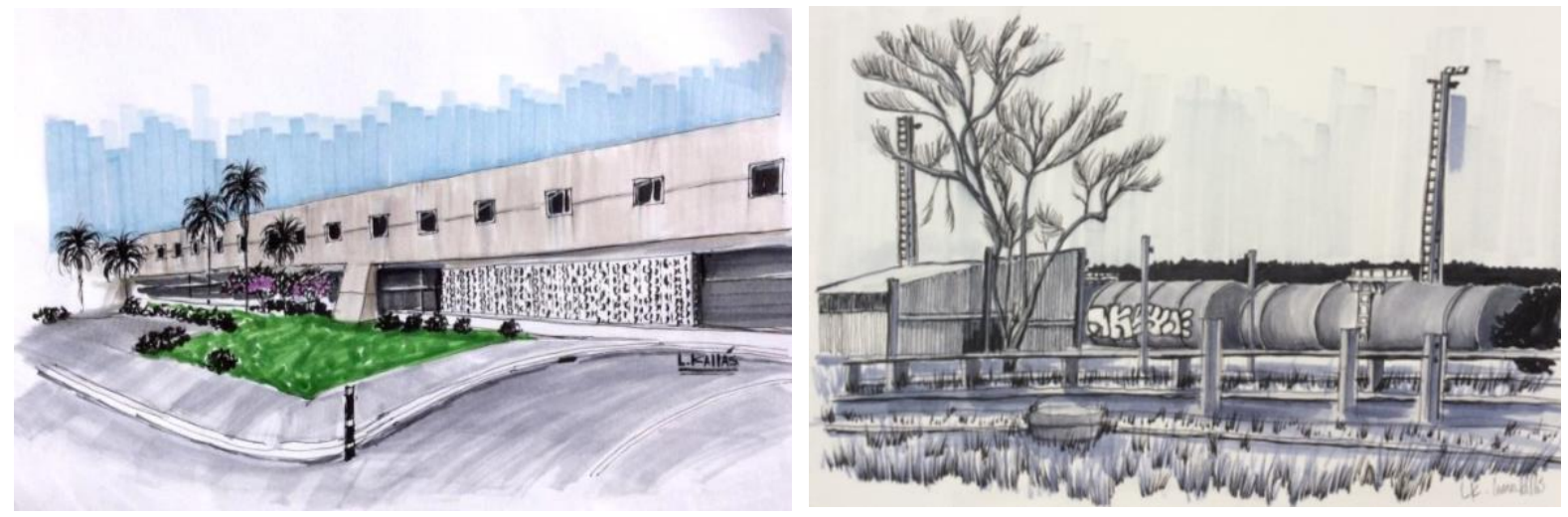

Figura 35. Parte frontal da Rodoferroviária, próximo à entrada principal, com parte da cerâmica de telefone do Athos Bulcão. Desenho: Luana Kallas, 2016.

Figura 36. Vagões de combustível, aparentemente abandonados no pátio férreo. Desenho: Luana Kallas, 2016.

\section{Conclusões}

O artigo buscou apresentar a história e a representação da antiga Estação Ferroviária de Goiânia e da antiga Rodoferroviária. Ficou evidente, que como a Estação Ferroviária de Goiânia é tombada possui mais informações e sua documentação está bem delimitada, assim como seu uso está bem definido nos dias atuais. Já a antiga Rodoferroviária de Brasilia, devido a sua história ter nascido com a construção de Brasilia, assim como a história da estação de Goiânia ter nascido com a cidade, a Rodoferroviária não possui tombamento, passou por duas reabilitações e hoje está ocupada apenas por órgãos públicos do GDF e a parte férrea é usada para o transporte de carga.

Nesse sentido, a história mostra a importância das duas estações para cada cidade, apesar da rodovia ter assumido o papel de principal modal no Brasil e as ferrovias terem perdido um pouco do papel de progresso. Mas a história e a memória estão presentes. Ainda nesse sentido, a documentação por sketches apresentada mostra um resgate e valorização da arquitetura e da cidade, que funcionam como educação patrimonial, uma vez que se refere ao valor e memória da cidade, uma vez que a antiga Rodoferroviária ainda não é tombada.

Ainda sobre a documentação por sketches é importante salientar que os desenhos junto às pequenas narrativas sobre o que se desenha apresentam-se como parte da educação, por possibilitar conhecer um pouco mais a cidade, proteger os bens imóveis de valor histórico resgatando de possíveis abandonos que são registrados e promovidos por meio da documentação dos sketches, uma vez que é uma linguagem que marca na memória.

Sobre a representação, como visto com os grandes mestres da pintura, é um registro no tempo e espaço que possibilita no futuro observar e identificar muito dos costumes, mesmo com outras formas de documentação. Nesse sentido, se verifica no sketch da estação de Goiânia e da Rodoferroviária a representação contemporânea, com técnicas mais flexíveis e incluem técnicas mais contemporâneas que reflete em mais formas de representar 
aquilo que se vê. Mas a contemporaneidade é claramente apresentada, com as estações e os elementos da história mais recente, como postes, automóveis, asfalto, o concreto das edificações e cerâmica estilizadas.

Esse estilo de representação possui semelhanças e diferenças. Na primeira, apresentam-se nas pinturas características do que se vê na contemporaneidade, assim como os mestres da pintura representavam a modernidade que havia chegado com a presença do ferro e do aço, como a locomotiva, a fumaça, como um símbolo da industrialização e as pessoas utilizando o espaço. Como diferenças, o tempo, os elementos da construção, na pintura dos mestres, tijolos aparentes, a vestimenta das pessoas características do início da industrialização; enquanto que, na contemporaneidade, a presença do revestimento, reboco e pintura, o concreto e a cerâmica estilizada, a presença dos automóveis, e a vestimenta contemporânea representada por alguns desenhistas de rua.

Quanto à história, Goiânia e Brasília em alguns momentos se cruzam, Brasília dependente de Goiás para a expansão da linha férrea para a chegada do desenvolvimento, uma vez que à época, o desenvolvimento era medido pela via férrea que um lugar dispusesse, dessa forma uma documentação histórica sobre as duas cidades também apresenta semelhanças, tais como:

- As duas cidades são do Centro-Oeste;

- A construção da linha férrea como forma de potencializar a expansão rumo ao oeste;

- A posição das referidas Estações Ferroviárias em relação ao projeto da cidade e às sedes administrativas;

- A representação de uma estação ferroviária e seus trilhos como elemento de modernização a acessibilidade às cidades;

- Brasília e a dependência dos trilhos da via férrea de Goiás para se tornar mais acessível e diminuir o tempo das viagens;

- A chegada da rodovia "ao lado" dos trilhos que deveria ter sido um modal complementar substituiu o modal ferroviário devido à política rodoviarista;

- Nas duas cidades, o tempo de uso como estação ferroviária foi breve em relação ao mesmo modal em outras cidades brasileiras;

- O tombamento urbanístico das duas cidades não inclui a área das Estações;

Assim como, diferenças também presentes relatadas a seguir:

- Estilos arquitetônicos distintos; a Estação Ferroviária de Goiânia é Art Déco, a Estação Ferroviária de Brasília é modernista.

- O edifício da antiga Estação Ferroviária de Goiânia foi tombado; a Rodoferroviária, não.

- Embora tombada, a Estação de Goiânia perdeu todo seu entorno para a urbanização e os diversos usos e ocupações do solo, alterando a paisagem; enquanto que a Estação de Brasília, apesar de ainda não ser tombada, tem mantido toda sua estrutura do entorno, com poucas modificações, mas sofre com as constantes "ameaças" de alteração de uso do solo pela proposta do PPCUB;

Quanto à representação, em relação as duas cidades objeto de estudo, possui mais semelhanças, que diferenças, pois a representação reflete o uso do espaço. No entanto, as semelhanças na representação dos desenhistas de rua atuais em relação aos mestres da pintura podem ser assim interpretadas:

- A representação do momento, a interpretação daquilo que se presencia e vivencia;

- A técnica de representação não é rígida, o uso de óleo, aquarela, carvão e outras técnicas podem ser visualizadas nas pinturas de alguns mestres da pintura, como também pelos desenhistas de rua;

- A representação dos elementos é livre "dentro do tempo" representado, ou seja, a modernidade e a contemporaneidade, respectivamente, mestres da pintura e desenhistas de rua atuais;

- Em ambos os casos, há uma registro, uma documentação da materialidade, espaço, tempo e pessoas, além das cidades, dos edifícios e das estações ferroviárias;

- A representação por sketches são uma forma de documentação das estações de Goiânia e Brasília, além de ser uma forma de conhecer a cidade, caminhando pela cidade e descobrindo seus lugares e detalhes. 
Nas diferenças, podem ser identificadas:

- Para a contemporaneidade, há a inclusão de uma técnica mais recente, o marcador como técnica de representação complementar ou substituindo a aquarela ou o óleo, por ser uma técnica mais rápida;

- Nos mestres do passado, as pessoas são representadas com maior realismo; enquanto que, para os desenhistas de rua atuais, há uma estilização da figura humana, não possuindo expressão, no entanto, existem as exceções.

- Nos desenhistas de rua atuais, há a presença de elementos da vida contemporânea, como veículos automotores, os postes com sua fiação elétrica e o asfalto;

Nesse sentido, o objetivo foi atendido, uma vez que a representação e a história das estações ferroviárias em Goiânia e em Brasilia foram documentadas em sketches, apresentando uma memória, de um espaço e tempo, indicando a materialidade do espaço registrado e a importância dos lugares para cada cidade.

Assim, espera-se que a documentação por sketches seja uma forma de resgate e valorização da cidade e da memória da cidade, representadas aqui pelo antigo edifício da Estação Ferroviária de Goiânia e da antiga Rodoferroviária de Brasília.

\section{Reierências}

Centro-Oeste. 1972(?). A nova estação de Brasilia. Disponível em: http://doc.brazilia.jor.br/Ferrovia-HistoriaBrasilia/1970-1972-projeto-Niemeyer-estacao-ferroviaria-Brasilia-maquete.shtml Acesso em 05 jun.2021.

Anos 1980 - Descompasso Coletivo. (2018). Correio Brasiliense. Série publicada de 15 de julho de 2018 a 22 de julho de 2018. Disponível em: https://especiais.correiobraziliense.net.br/conexaobrasilia/\#!/post/1980. Acesso em: 05. jun. 2021.

Anuário RF 2015. (2015). O mais completo guia do setor metroferroviário brasileiro. Ano 5. No5.

Benjamin, W. 1892-1940. (2007). Passagens. Belo Horizonte: Editora UFMG; São Paulo: Imprensa Oficial do Estado de São Paulo.

Brandão, S. B. (2016). A antiga linha férrea de Goiânia. Símbolo da modernidade à obsolescência. Dissertação (Mestrado em Projeto e Cidade) Programa de Pós-Graduação Projeto e Cidade, Universidade Federal de Goiás, Goiânia, 2016.

Decreto $n^{\circ}$ 41.193, de 26 de Marco de 1957. Atribui a Companhia Urbanizadora da nova Capital do Brasil os estudos e construção de linhas férreas de interêsse do futuro Distrito Federal. Lex. DOU de 27 e 28/03/1957. Seção 1. p. 7221.

Brasília construirá moderna estação ferroviária em 2 anos. (1970, julho-agosto). Revista Refesa, p. 30. Disponível em: http://doc.brazilia.jor.br/Ferrovia-Historia-Brasilia/1970-1972-projeto-Niemeyer-estacao-ferroviaria-Brasiliamaquete.shtml. Acesso em: 05. Jun.2021.

Brasília. (1957a). Revista da Companbia Urbanizadora da Nova Capital do Brasil. Número especial de 04.1957. Ano 1. No 04.

Brasília. (1957b). Revista da Companhia Urbanizadora da Nova Capital do Brasil. Número especial de 07.1957. Ano 1. No 07.

Brasília. (1957c). Revista da Companbia Urbanizadora da Nova Capital do Brasil. Número especial de 8.1957. Ano 1. No 8.

Brasília. (1957d). Revista da Companhia Urbanizadora da Nova Capital do Brasil. Número especial de 9.1957. Ano 1. No 9.

Brasília. (1957e). Revista da Companhia Urbanizadora da Nova Capital do Brasil. Número especial de 11.1957. Ano 1. No 11.

Brasília. (1958a). Revista da Companbia Urbanizadora da Nova Capital do Brasil. Número especial de 18.1958. Ano 2. No 18.

Brasília. (1958b). Revista da Companbia Urbanizadora da Nova Capital do Brasil. Número especial de 19.1958. Ano 2. No 19.

Brasília. (1958c). Revista da Companbia Urbanizadora da Nova Capital do Brasil. Número especial de 21.1958. Ano 2. No 21. 
Brasília. (1958d). Revista da Companbia Urbanizadora da Nova Capital do Brasil. Número especial de 22.1958. Ano 2. No 22.

Cavalcanti, F. R. (2013, dezembro). Esplanada Ferroviária de Brasília - A discussão do PPCUB 2013, Plano de Preservação do Conjunto Urbanístico de Brasília. Disponível em: http://doc.brazilia.jor.br/ferroviaBrasilia/esplanada-ferroviaria-PPCUB-2013.shtml. Acesso em 05 jun. 2021.

Centro-Oeste. (2005). Estação de Brasilia - Como ficou. Disponível em: http://doc.brazilia.jor.br/ferroviaBrasilia/estacao-ferroviaria-Brasilia-invasao-quiosques.shtml. Acesso em 05 jun. 2021.

Choay, F. (1999). Alegoria do Patrimônio. Lisboa: Edições 70, (70 Arte e Comunicação). Tradução: Teresa Castro.

Cidades. (2010). Desde a inauguração da nova Rodoviária, o antigo terminal está às moscas. Correio Brasiliense. Postado em 15/11/2010. Disponível em:

https://www.correiobraziliense.com.br/app/noticia/cidades/2010/11/15/interna_cidadesdf,223140/desde-ainauguracao-da-nova-rodoviaria-o-antigo-terminal-esta-as-moscas.shtml. Acesso em: 05. jun. 2021.

Coelho, G. N. \& Valva, M. d’A. (Orgs.). Goiânia: a história em documentos. Goiânia: Trilhas Urbanas. 2018.

Costa, L. (1957, julho). Relatório do Plano Piloto de Brasília. In: Módulo, n.8, p-33-48.

Del Rio, V. (2016). Perambulando pelo centro histórico de Lisboa: urbanidade, o flâneur e as qualidades visuais da cidade. In: P. Rheingantz, R. Pedro \& A. Szapiro (Orgs.), Qualidade do Lugar e Cultura Contemporanea. Porto Alegre: Editora Sulina, 2016.

Estrada de Ferro Central do Brasil. (2021). In: ENCICLOPÉDIA Itaú Cultural de Arte e Cultura Brasileiras. São Paulo: Itaú Cultural. Disponível em: <http://enciclopedia.itaucultural.org.br/obra1617/estrada-de-ferro-central-do-brasil>. Acesso em: 01 jun. 2021. Verbete da Enciclopédia. ISBN: 978-85-7979-060-7.

Ferrovias para Brasília - 1968 : $1^{\circ}$ Trem em Brasília. (1968, março-abril). Revista Refesa, pp. 4 a 7. Disponível: http://doc.brazilia.jor.br/Ferrovia-Historia-Brasilia/1968-04-21-chegada-primeiros-Trens-Brasilia.shtml. Acesso em: 05. jun. 2021.

Frei, N. C. (2021). In: ENCICLOPÉDLA Itaú Cultural de Arte e Cultura Brasileiras. São Paulo: Itaú Cultural. Disponível em: <http://enciclopedia.itaucultural.org.br/pessoa23212/frei-nazareno-confaloni>. Acesso em: 19 jun. 2021. Verbete da Enciclopédia. ISBN: 978-85-7979-060-7.

Goiânia. (s/d). Prefeitura de Goiânia. História de Goiânia. Disponível em: https://www.goiania.go.gov.br/sobregoiania/historia-de-goiania/. Acesso em: 15 set. 2020.

Governo Distrito Federal (DF).(2017). Proposta de Minuta de Lei (2017). Proposta de Minuta PLC PPCUB, de 2017. Aprova o Plano de Preservação do Conjunto Urbanístico de Brasília - PPCUB e dá outras providências. Lex: Proposta de Minuta de Lei. ed. Brasilia, DF: Projeto de Lei Minuta PLC. Disponível em: http://www.seduh.df.gov.br/wpconteudo/uploads/2017/11/Minuta-PLC-PPCUB.pdf. Acesso em: 16 nov. 2020.

Guedes, R. S. \& Queiroz, C. J. P. V. de. (2007, outubro). A Reciclagem da Estação Ferroviária de Brasília. In: Anais do $7^{\circ}$ seminário do.co.mo.mo Brasil. O moderno já passado | o passado no moderno - reciclagem, requalificação e rearquiettura. Porto Alegre.

Guimarães, L. D. S. (2019). Ideia, obra e concretude: representações na construção de Goiânia. Dissertação (Mestrado em Arquitetura e Urbanismo) - Instituto de Arquitetura e urbanismo, Universidade de São Paulo, São Carlos.

Instituto Brasileiro de geografia e estatística. (1954). I Centenário de Ferrovias brasileiras. IBGE: Rio de Janeiro,1954.

Kallas, L. M. E., Silva, E. A. S. da, \& Guillen-Salas, J. C. O patrimônio edificado e urbanístico do plano piloto de Brasília [DF]: documentação, valorização e resgate por meio dos 'sketches'. Labor e Engenho, Campinas, SP, v. 14, p. e020014, 2020. Disponível em: https://periodicos.sbu.unicamp.br/ojs/index.php/labore/article/view/8663414. Acesso em: 7 jun. 2021.

Kallas, L. M. E.; Guillen-Salas, J. C., \& Silva, E. A. S. da. Resgate, valorização, educação e documentação do patrimônio por meio de sketches. Revista Jatobá, v. 2, 9 nov. 2020. Recuperado de https://www.revistas.ufg.br/revjat/article/view/66526. Acesso em: 10 nov. 2020.

Lambert, N. \& Cavalcanti, L. (2017). Falta de planejamento em ferrovias causam prejuizos 50 anos depois. Disponível em: https://www.correiobraziliense.com.br/app/noticia/brasil/2017/04/02/interna-brasil,585446/falta-deplanejamento-em-ferrovias-causam-prejuizos-50-anos-depois.shtml. Acesso em: 05. jun. 2021. 
Manso, C. F. A. (2001). Goiânia: uma concepção urbana, moderna e contemporânea - um certo olhar.

Niemeyer, O. (s.d.) [EFB - estudo preliminar]. Fundação Oscar Niemeyer. Coleção Oscar Niemeyer.

Niemeyer, O. (1973). Terminal rodoferroviário - Rodoferroviária de Brasília. Fundação Oscar Niemeyer. Coleção Oscar Niemeyer. Disponível em: http://niemeyer.org.br/obra/pro224. Acesso em: 05. jun. 2021.

Oliveira, M.M de. (2016). Como fazer pesquisa qualitativa. 7. Ed. Revista e atualizada. Petropolis, RJ: Vozes.

Pátio de Brasília será o maior. (1970, novembro-dezembro). Revista Refesa. Disponível em: http://doc.brazilia.jor.br/Ferrovia-Historia-Brasilia/1970-esplanada-patio-ferroviario-Brasilia.shtml. Acesso em 05 jun.2021.

Silva, E. A. S. da. (2012). O espaço e o tempo: transformações no desenho do plano piloto de Brasília. Tese (Doutorado em urbanismo). Programa de Pós-graduação em Urbanismo - Universidade Federal do Rio de Janeiro.

Silva, K. M. (2019) Camadas do tempo: representações geográficas nas fotografias e cartões postais da cidade de Goiânia (1933 - 1970). Tese (Doutorado em Geografia) - Universidade Federal de Uberlândia, Uberlândia.

Trem Bandeirante: Campinas-Brasília. (1981). A reinauguração (1981). Programa de viagem especial do Bandeirante entre São Paulo e Brasília. 27/28 de abril de 1981. Disponível em: http://doc.brazilia.jor.br/Ferrovia-Historia-Brasilia/1981reinaugura-Trem-Bandeirante-Campinas-Brasilia.shtml. Acesso em: 05. jun. 2021.

Urban Sketchers (Global). (2021). Our Manifesto. Disponível em: http://www.urbansketchers.org/p/ourmanifesto.html. Acesso em: 05 jun. 2021.

Van Gogh. (1890, june). The letters of Vincent Van Gogh (1853-1940) - letter 886 To Willemin Van Gogh. Auvers, Friday.

Zucconi, G. (2009). A cidade do Século XIX. São Paulo: Perspectiva. 